\title{
The Rise of Operation Reinhard
}

Soon after the start of the Nazi regime's furtive T4 euthanasia project in 1939, rumors spread that the Nazi regime was killing Germans with disabilities. On 8 July 1940, for example, a provincial probate judge wrote in a letter to the minister of justice, "'Everyone knows as well as I do' that "the murder of the mentally ill is as well known a daily reality as, say, the concentration camps." These suspicions were confirmed when some of the victims' families received death certificates claiming clearly spurious causes of death. Some said that victims who had long ago had their appendixes removed died of appendicitis. ${ }^{2}$ Heated and public protests ensued-most notably led by Count Clemens August von Galen, the Archbishop of Münster. ${ }^{3}$ The Nazis may have been a dictatorship but they knew, as all long-lasting autocracies do, broad public dissent does not bode well for political longevity. For this reason, Hitler had always been sensitive to the emotional vagaries of public opinion. ${ }^{4}$ After placing the popular and potentially influential von Galen under house arrest, on 24 August 1941, the Führer ended, at least officially, the euthanasia program. ${ }^{5}$ At just the same time, however, the Eastern shooting campaign was expanding and, because these massacres were causing psychological problems for many shooters, Nebe and Fritzsch were about to embark on their search for a more "humane" way of killing civilians (ending in their discoveries of two cheap and mobile gassing techniques).

This chapter details what evolved into the large-scale gassing programs in the East, with a particular emphasis on Operation Reinhard-the extermination of Jews in the city ghettos of the General Government.

(C) The Author(s) 2019 https://doi.org/10.1007/978-3-319-97999-1_6 
What follows shares much in common with the pattern of escalation depicted in the previous chapters: initially low rates of killing, top-down pressure to increase those rates, the application of formal rationality from the bottom-up (increased experimentation, bureaucratization, and the honing of a less stressful killing process), resulting in increased kill rates that only served to stimulate new top-down pressures to meet new and even more ambitious goals, thus occasioning an ever-expanding cycle of destruction. Much like with the shootings, top-down and bottom-up forces "radicalized each other." Much like Milgram's pilot studies where all the kinks in his increasingly powerful procedure were ironed out, with time and experience the key innovators during this gassing program also ironed out every kink that threatened their goal-kill every person sent their way. As we shall see, the result was Operation Reinhard, an increasingly efficient program that killed between 1.5 and 1.7 million people in just 20 months.

\section{New Opportunities}

With the suspension of T4's euthanasia program, individuals who had developed an expertise in gassing civilians suddenly found themselves out of work. One such person, the previously mentioned chemist August Becker, later explained what the SS-Reichsführer had planned for them: "Himmler wanted to deploy people who had become available as a result of the suspension of the euthanasia program, and who, like me, were specialists in extermination by gassing, for the large-scale gassing operations in the East which were just beginning."7 Becker notes in more detail,

When in December 1941 I was transferred to Rauff's department he explained the situation to me, saying that the psychological and moral stress on the firing squads was no longer bearable and that therefore the gassing programme had been started. He said that gas-vans with drivers were already on their way to or had indeed reached the individual Einsatzgruppen. My professional brief was to inspect the work of the individual Einsatzgruppen in the East in connection with the gas-vans. This meant that I had to ensure that the mass killings carried out in the lorries proceeded properly. ${ }^{8}$

From November onward, ${ }^{9}$ the Einsatzgruppen received at least 15 gas vans fitted out with Nebe's exhaust innovation: Einsatzgruppe 
A two; Einsatzgruppe B four; Einsatzgruppe C five; and Einsatzgruppe D four. ${ }^{10}$ The inventive chemist, Albert Widmann (from the RSHA's Criminal Technology Institute), was on hand to provide the execution squads with assistance and advice on using the vans-a role Becker would soon fill. A member of Blobel's squad by the name of Lauer described what Spektor believes was the earliest documented gas van operation on Soviet territory. In November 1941:

Two gas vans were in service. I saw them myself. They drove into the prison yard, and the Jews-men, women, and children-had to get straight into the vans from their cells. I also know what the interior of the vans looked like. It was covered with sheet metal and fitted with a wooden grid. The exhaust fumes were piped into the interior of the vans. I can still hear the hammering and the screaming of the Jews-'Dear Germans, let us out!'l1

The gas vans enabled the executioners to avoid the stressful visual spectacle associated with guns, but clearly they failed to shield them from the noise generated by those dying inside. A witness, Eugenia Ostrovec, described tactics reminiscent of Milgram's participants talking over the learner's screams in an attempt to neutralize this remaining source of perceptual information. "When it was quite full, the doors were firmly locked. The driver started the engine and left it running at full revs, but he couldn't drown the cries of the prisoners and the trampling of feet inside the van." 12 Although some gas van operators certainly used the truck's motor to help neutralize the victims' screams, Becker's report to Berlin of 16 May 1942 reveals that this was unlikely the only reason for pressing on the accelerator: "In order to get the Aktion finished as quickly as possible the driver presses down on the accelerator as far as it will go." 13

Because the original euthanasia program had used canisters of pure carbon monoxide, which is both odorless and colorless, ${ }^{14}$ gassing technicians were more likely to have been spared the cries of panicking victims. In those cases, by the time the condemned realized what was happening to them, it was generally too late to react. On the other hand, the malodorous and visible diesel fumes used in the vans left victims alert to the presence of great danger and they reacted with desperation. They produced frightful sounds that proximate perpetrators found difficult to avoid. 
But for the perpetrators, the sounds of dying people were not the only disturbing source of perceptual stimulation they encountered. Blobel's chauffeur described the visual spectacle that greeted perpetrators once the victims were killed. "The back doors of the van were opened, and the bodies that had not fallen out when the doors were opened were unloaded by Jews who were still alive. The bodies were covered with vomit and excrement. It was a terrible sight." 15 Faced with such a sight, the mentally fragile Blobel "looked, then looked away, and we drove off. On such occasions Blobel always drank schnapps, sometimes even in the car." 16 Perhaps fearing Heydrich's accusations that he was "soft," 17 the attentive and pandering Blobel was determined to complete his distasteful assignment. Blobel's avoidance behavior is reflected in a report sent from RSHA chief mechanic Pradel to Rauff on 5 June 1942 on ways to improve the vans. "The observation windows that have been installed," which helped the perpetrators determine if the victims had died, "...could be eliminated, as they are hardly ever used." 18

While Einsatzgruppe C came to depend on their gas vans, other squads made little or no use of them, preferring instead to continue shooting their victims. Becker implied a reason for this in a report he sent to Berlin on 16 May 1942:

I would like to take this opportunity to draw your attention to the following: some of the Kommandos are using their own men to unload the vans after the gassing. I have made commanders of the Sonderkommandos in question aware of the enormous psychological and physical damage this work can do to the men, if not immediately then at a later stage. ${ }^{19}$

Where Blobel's men had Jews unload the vans, other Einsatzgruppen units decided, for security reasons, to deploy their own men to perform this harrowing task. ${ }^{20}$

For many perpetrators, it was important to kill victims as quickly as possible. In this respect, the gas vans were clearly inferior to a bullet in the back of the neck. Although the gas vans enabled the Germans to avoid having to see their victims die, the prolonged screaming and the visual spectacle after the back doors of the van were opened made it difficult to deny the reality that their victims had died slow and agonizing deaths. Consequently, some of the Einsatzgruppen commanders and their men formed the opinion that compared with the neck shot, the 
vans actually caused greater emotional stress for perpetrators. The verdict of a 1972 court case in Munich stated,

The defendant Schuchart declared to a member of the commando that personally he would have preferred to be shot rather than gone into the truck. When the doors were opened the bodies were all entangled and covered with excrement. As a result of complaints from members of the commando, the defendant Schuchart later refused to use the gas vans again, on the grounds that it was impossible to persuade his men to carry out such a task. $^{21}$

Of course, forcing Jews to remove their own people from the vans meant the executioners could, if they so desired, avoid the perceptual realities of their genocidal contributions. ${ }^{22}$

Indeed, the inventors of the gas van paid little attention to the slow and painful manner of their victims' deaths because their search for a more "humane" method centered, first and foremost, on alleviating the executioners'-not the victims'-psychological stress. The members of the Einsatzgruppen tasked with using these vans then faced what they would have interpreted as a moral dilemma: to use firearms that killed instantly and were arguably less painful for the victims, but generated an unavoidable visual spectacle that inflicted an immediate and lasting psychological burden on the shooter, or to use gas vans that could eliminate any disturbing visual spectacles for themselves, but inflicted a cruel and prolonged death on the victims. Many German executioners believed the gas van to be an inhumane and "cowardly" means of inflicting death. As Hans Stark said of the gas vans during his trial after the war:

"It was a terrible sight." Judge Hofmeyer: "Did the people appear to have gone through an agonizing death struggle?" "I didn't look closely; one glimpse was enough for me." "How did you feel?" "Never again." "Why? Did you think it was wrong?" "No, certainly not." "Well, then, why "never again' if it was right and necessary?" "When someone was shot it was entirely different, but the use of gas was not manly, it was cowardly." 23

There were other problems too. It did not help matters that the vans struggled to master the frequently muddy Soviet late-fall terrain. Also, the Einsatzgruppen's 15 or so vans could not match the killing efficiency of a mass shooting like Babi Yar. ${ }^{24}$ Hilberg is correct: In the end, 
Nebe's gassing innovation was not the killing "panacea" that Himmler and many shooting squad members were hoping for. ${ }^{25}$ Many of the men returned to shooting or simply passed this dirty work on to their Eastern European collaborators. It transpires, however, that another group outside the Einsatzgruppen-the euthanasia program's Lange Commando-also received several exhaust fume gas vans. And in the hands of T4 gassing professionals like Lange, Nebe's innovation went on to have, as we shall see, devastating consequences for those Jews and Gypsies still alive in the Wartheland.

\section{The Origins of the First Extermination Camp: Chęmno}

It will be recalled that based on Himmler's mid-October 1941 instructions to Eichmann, Lódź was to be one of the four cities to receive trainloads of Western Jews. More precisely, on 18 September, Himmler wrote to Wartheland Governor Arthur Greiser and told him to expect the arrival of 60,000 Western Jews, all of whom were apparently to be moved further east the following spring. ${ }^{26}$ Greiser negotiated this number down, and across October and November, 20,000 Western Jews and 5000 Austrian Roma Gypsies were sent to the already over-crowded Lódź ghetto. ${ }^{27}$ How the Lódź ghetto was supposed to accommodate this large influx of people-where that winter officials like RolfHeinz Höppner expected many Jews would starve-was now Greiser's problem. Lódź's Jewish council would not have welcomed Himmler's news: The resettlement of so many relatively rich Western Jews into the ghetto would likely accentuate starvation among the poorest Polish Jews because the former's greater wealth would cause the general cost of food to rise. ${ }^{28}$ In a panic, Greiser instructed Wilhelm Koppe, Lange's superior officer, to somehow find a way of ensuring the ghetto could accommodate this large influx of newcomers. ${ }^{29}$ It is no coincidence that around this point in time the Lange Commando went from gassing Poles with disabilities (T4) to exterminating the potentially far more numerous Wartheland Jews (and others). ${ }^{30}$ Lange and his men were unlikely fazed by this sudden change to a more numerous victim category: A proportion of their usual victims had been Jewish and, anyway, others elsewhere over the last few months had been shooting Jews en masse. Because Greiser and those below him like Marder and Biebow were, as Browning argues, committed "productionists," Lange was instructed to kill only non-working Jews. ${ }^{31} \mathrm{He}$ could not, however, set out by killing 
non-working Jews in the Lódź ghetto-word of his instructions might spread panic among his main target population. Lange needed to start somewhere else- a more isolated locale where he could hone an increasingly refined large-scale killing operation.

The Lange Commando's “opening salvo" on the Jews was aimed at those living in the Grodziec and Rzgów ghettos in Konin County, located about 100 kilometers northwest of Lódź. ${ }^{32}$ Although the details surrounding this massacre are hazy at best, evidence suggests that across several days in late September and early October 1941, the Lange Commando very likely gassed and probably shot about 1500 Jews. ${ }^{33}$ Then, after gassing 290 elderly Jews in late October about 50 kilometers to the south of these ghettos, ${ }^{34}$ Lange's men soon returned to Konin County. This time the Lange Commando had the much larger rural ghetto in Zagórów-about 3000 non-working Jews-in their sites. ${ }^{35}$ Facing this larger victim pool, Lange must have wondered how, armed with one gas van dependent on limited supplies of gas canisters and 15 or so armed men (with no Jeckeln-style mass shooting experience), his commando was supposed to quickly exterminate so many people. It appears Lange, facing this killing conundrum, did what other rational problem-solvers a month or two before him did in places like Minsk, Mogilev, Lublin, Auschwitz I, and Mauthausen. That is, from the bottom-up, as best he could, Lange improvised and invented a potentially effective means of meeting his top-down superior's demands to rapidly kill large numbers of civilians: He "experimented with a new form of killing." 36 In doing so, Lange obviously hoped that his newly devised method would provide sufficient room for the large influx of Western Jews that had arrived or were heading to the Lódź Ghetto. According to one non-Jewish Polish prison laborer Mieczysław Sękiewicz, around mid-November 1941, the Zagórów Jews were transported to a nearby forest. In the forest, two large pits had been dug, the larger of which had been layered with chunks of unslaked lime. Lange's men then ordered the naked Jews to enter and stand in the larger pit. From "above the only thing visible was the heads of the people, tightly packed in the pit." 37 Then, according to Sękiewicz:

I noticed four vat-like things on the truck. Next, the Germans set up a small engine, which was probably a pump. Using a hose, they connected it to one of the vats. Two of the Gestapo officers then dragged the hose from the motor to the large pit. They started the motor and these two Gestapo 
officers holding the hose began pouring something onto the Jews crowded in the pit. I think it was water, that's what it looked like but I'm not sure [...] Apparently, as a result of the slaking of the lime, the people began to boil alive. The screaming was so horrible that those of us who were sitting near the clothing tore off pieces of material and put them in our ears. The horrible screams of those being boiled in the pit was joined by the screaming and wailing of those still waiting to be executed. That lasted for about two hours, possibly longer. ${ }^{38}$

The next day Sękiewicz observed that "[ $\mathrm{t}]$ he mass of people inside had collapsed and sunk towards the bottom of the pit. The bodies were packed so tightly together that they remained in the somewhat vertical position; only their heads were tilted in all different directions." ${ }^{39}$ Lange must have assessed his experiment a failure because despite the slacked lime achieving his goal-in just a few hours a large number of Jews had been killed-the commando gassed the remaining victims. ${ }^{40}$ Presumably, the Germans, again with themselves in mind, found this new killing method too harrowing.

Around the time of this massacre, that is mid-November, commando member Walter Burmeister recalled driving Lange to Berlin. ${ }^{41}$ Around the period of Lange's stay in Berlin, T4 leader Karl Brandt perhaps caught wind of Lange's disturbing experience when trying to quickly exterminate large numbers of Polish Jews and aware that contemporaneously the Einsatzgruppen were receiving the latest in gas van technology, deemed it wise to direct a few of Nebe's vehicles to the Wartheland. More certainly, Brandt informed Koppe (Lange's superior) that "the 'testing of Brack's [Nebe's] gas' was planned for the Warthegau [Wartheland]." ${ }^{2}$ Lange returned to his team in Poznań with instructions to set up a new permanent base close to the Lódź ghetto. ${ }^{43}$ With his preconceived goal to construct a permanent gassing facility, Lange in the role of the problem-solving project manager kicked into action. First up, he needed a location, more manpower, and, upon the arrival of his new fleet of gas vans, an efficient extermination process. Nearing the very end of 1941, Lange selected a castle with a large basement located in the small township of Chełmno. ${ }^{44}$ Lange found the castle attractive for several reasons: It was secluded in a quiet rural setting yet connected to road and rail networks. Also, Chełmno was centrally nestled among the largest Jewish populations living in the Wartheland, ${ }^{45}$ particularly the Lódź ghetto only 60 kilometers away. ${ }^{46}$ Seclusion was important 
because, again, Lange's deadly assignment had to remain a secret from his Jewish targets. But with several Jewish communities living within a five- to 15-kilometer radius of the castle, Chełmno's prized central location also threatened to reveal its dark secret. Once Lange had recruited more manpower, he would need to neutralize this threat to preconceived goal achievement.

After the Konin County massacre, Lange's usual crew was sent to Chełmno. In need of more staff, Lange had increasing numbers of police officers based in Lódź transferred to his new camp. One of Lange's recruitment and retention strategies was, much like Milgram, to anticipate his prospective helpers' likely needs and desires. For example, one technique Lange relied on was the lure of pecuniary reward: On top of their usual salary, his German staff, much like those in the shooting squads, ${ }^{47}$ "received a daily bonus of 12 Reichsmarks that doubled their pay relative to the others...." 48 On top of this, Lange gave his men special allotments of liquor and cigarettes. ${ }^{49}$ One of the police transferees from Lódź was Alois Häfele, who arrived at Chełmno with some of his men around January 1942. On arrival, Lange told Häfele and his men that he (Lange) had been tasked with gassing local Jews, but in order to fulfill his orders he needed more manpower. According to Häfele, Lange added that to maintain secrecy about Chełmno's purpose, he only needed the new recruits to perform guard duties and thus "We would have nothing to do with the extermination of the Jews themselves." 50 Lange's attempt to recruit these policemen by suggesting they only had to perform ancillary (yet necessary) tasks is, again, somewhat similar to Milgram's Peer Administers Shock condition. Then again, Lange's strain resolving inducement may actually have been more congruent with the foot-in-the-door technique. That is, soon after Häfele committed himself to performing mere guard duties, he became more intimately involved in the killing of Jews and eventually became a key figure in the camp's extermination process. ${ }^{51}$ Because Lange's orders had come from the very top of the Nazi hierarchy, he also alluded to the great national importance attached to them. As another camp guard Kurt Möbius said: "Hauptsturmführer Lange had told us that the orders concerning the annihilation of the Jews had been given by Hitler and Himmler." 52

But if Lange intended to increase the scale of killing, who would he burden with the more arduous and repulsive tasks that his German staff were likely to shy away from? During the period he was setting up Chełmno, Lange returned to the prison at Fort VII and paid his old 
Polish work commando a visit. On meeting with his old body disposal unit, Lange commented on their poor and somewhat emaciated physical condition and then supplied them with a meal of bread and sausages. Lange then informed the Poles that, if they were interested, he could really use their help on a new operation. ${ }^{53}$

Like all good project managers, Lange knew just what to say and do to get every diverse link in his anticipated organizational chain interested in working toward goal achievement. Because Lange utilized sometimes different routes when attempting to anticipate and then appeal to his helper's sometimes different motivational needs and desires, like Milgram, he was able to find a way of getting each of them on board with organizational goal achievement. Some signed on because they would make a rather generous living, there were promotional opportunities, and perhaps they saw great merit in Nazi ideology. Others might well have felt indifferently toward or even disagreed with Nazism, but during hard and dangerous times, who is going to turn down a wellpaid and (relatively) safe job likely to come with lots of material perks? Some of Häfele's men, for example, might have accepted Lange's generous employment offer because of a preference to remain among an old and trusted group of comrades-people of great personal importance with whom they would do anything to remain on good terms with. And perhaps being involved in a top secret mission personally backed by Himmler and Hitler was enough to pique the interest of the more ambitious among them. For the most desperate of those Lange approached, clearly all it took was the offer of a decent meal and the opportunity to see another day. This is how Lange enhanced what organizational theorists term employee "performance motivation...." 54

Interestingly - and in conflict with Goldhagen-like single motivational explanations of the Holocaust-Lange's reliance on various means of incentivizing his workforce illustrates the insufficient singular force of Nazi ideology. ${ }^{55}$ On this note, although Lange was no doubt a strong-believing Nazi, it is unlikely he would have been concerned that some of his prospective helpers might have ardently disagreed with his politics or even Chełmno's organizational goal—all he cared about was that they performed their specialist roles. And much like Himmler and Heydrich before him, Lange did everything he could to make sure all those below him did just that. On the frequently discussed issue of perpetrator motivation during the Holocaust, as Kühl forcefully argues, 
the motives for an organization member's actions play a subordinate role for the organization because organizations ultimately disregard the concrete motives of their members when they formulate behavioral expectations. Whether members meet an organization's formal expectations because of their identification with the goal, coercion, collegiality, money, or enjoyment of the activity is of secondary importance - just as long as they do it. The unsettling aspect from a sociological viewpoint is that, when it comes to organized violence, the motives driving people to participate in torture, shootings, or gassings are incidental. In the end, all that matters to the organization is that its members do what is expected of them.... ${ }^{56}$

Nearing the end of 1941, some Polish prisoners and locals from the surrounding area were tasked with renovating the Chełmno castle. ${ }^{57}$ It took them about a month to set the camp up, ${ }^{58}$ upon which Lange's old guard addressed the previously mentioned threat to secrecy posed by those Jewish communities who lived near the castle. That is, between 8 and 11 December, Koło's Jewish community, just 14 kilometers away, were rounded up and killed in Lange's old gas van (thus using canisters of carbon monoxide), and then buried in a nearby forest. ${ }^{59}$ These local Jews became Chełmno's first victims. As 1941 came to an end, Lange's men proceeded to exterminate nearly every Jewish person living within a 20-kilometer radius of the camp. ${ }^{60}$ Consequently, secrecy about Chełmno was secured, at least among the remaining Wartheland Jews. Then, in early January 1942, Lange's men received orders to kill another new category of victim: the previously mentioned 5000 Austrian Roma Gypsies, who only two months earlier had arrived in the Lódź ghetto. It transpires that these Gypsies were restricted to a small and isolated corner of the ghetto, ${ }^{61}$ and their living conditions were so atrocious that most of them contracted typhus. ${ }^{62}$ In a desperate rush to inhibit the infectious disease from spreading, fix-it-man Lange received a call from his superiors. It took the commando eight days to gas and shoot the Gypsies, a task for which a no doubt grateful Lódź ghetto administration paid Lange 20,000 Reichsmarks. ${ }^{63}$ But as far as Lange's main goal was concerned, the most important event around this point in time was that in January 1942, three new vans fitted with Nebe's innovation arrived at Chełmno. ${ }^{64}$ After the camp infrastructure had been constructed, these vans suddenly provided Lange with access to a much cheaper, more abundant, and accessible source of gas. It was from this point onward 
that Lange's men were able to start making major in-roads into their goal to eliminate non-working Jews in the Wartheland. However, just as the Lange Commando was about to convert their goal into reality, a few events that were to have a major bearing on the course of World War Two took place.

\section{Centralization of the Extermination Process: The Wannsee Conference}

In early to mid-December 1941 as Lange set up his camp, as mentioned, the German advance into the Soviet interior was repelled by a forceful Russian counteroffensive and the USA entered the war. At this time, Hitler informed his inner circle that all European Jews-Eastern and now also Western-were to experience a "clean sweep." Hitler's intentions at the private 12 December meeting appear to closely mirror his public threat issued back on 30 January 1939 to annihilate "the Jewish race in Europe." As the Training Journal of the Order Police dated December 1941 notes, the significant difference between early 1939 and late 1941 was that advances in capability had made Hitler's threat of extermination technically feasible.

The word of the Führer [in his speech of January 1939] that a new war, instigated by Jewry, will not bring about the destruction of anti-Semitic Germany but rather the end of Jewry, is now being carried out. [...] What seemed impossible only two years ago, now step-by-step is becoming a reality: the end of the war will see a Europe free of Jews. ${ }^{65}$

Now, the challenge to Nazi plans came from another source, a more difficult war on the Eastern, Western, Italian, and African fronts and the consequent need to find all the help they could to win the war. ${ }^{66}$ The regime's desperation for slave labor meant it could ill afford to exterminate all Jews at that time. With respect to both the Jewish question and the threat of the Allied forces, the Nazi regime needed to seriously and quickly reassess their plans of attack.

The latest policy on the Jewish question was to be revealed at Heydrich's Wannsee Conference on 9 December. However, because Hitler had recently declared war on the USA, emergency military preparations dictated that some of the invitees could not attend. Also, the new Chief of KdS Latvia, Rudolf Lange, who according to Angrick and Klein 
"had without a doubt been accorded by Reinhard Heydrich a special role at this meeting," was, for reasons that will become apparent, also unable to attend. ${ }^{67}$ The Wannsee Conference was, therefore, postponed until 20 January 1942. In terms of the agenda, the only major difference between the proposed 9 December meeting and the 20 January postponement was, somewhat curiously, the addition to the original invitee list of two high-ranking officials from the General Government: Hans Frank and Friedrich-Wilhelm Krüger (both of whom ended up sending their assistants). ${ }^{68}$ David Cesarani argues that Heydrich's addition of representatives from the General Government to the invitee list suggests either an earlier oversight or, more intriguingly, that in light of Hitler's 12 December inner-circle meeting, the purpose of the Wannsee Conference had been broadened beyond the deportation of just Reich Jews to the Ostland. ${ }^{69}$

On 8 January, Göring issued a decree on labor policy. All Soviet POWs - the Nazis' preferred, but now diminishing, source of slave labor-were henceforward to be assigned only to the all-important production of armaments. ${ }^{70}$ These and other major policy changes indicated that the Nazi regime had plans in the spring to bounce back from its recent military setbacks.

When the Wannsee Conference finally went ahead, 14 mostly state secretaries and other high-ranking government officials were in attendance. The relatively lowly ranked shooting squad leader Rudolf Lange and Eichmann were also there, with the latter (or his assistant) tasked with taking the minutes, which were not verbatim. These minutes, however, are the only record of what was said. To these men, Heydrich revealed the latest plan to resolve the Nazis' "Jewish problem." Heydrich started the meeting by repeating Göring's 31 July mandate that delegated to him [Heydrich] full authority for resolving the "Jewish question."71 As he asserted his authority, Heydrich made it clear that there were to be no other competitors secretly working toward the Führer's wish, only collaborators. Previously failed attempts at resolving this question were discussed, as was a new solution that the Führer had apparently authorized. ${ }^{72}$ More specifically, a country-by-country survey showed that about 11 million Jews lived in Europe. ${ }^{73}$ To deal with this population, the entire continent was to be "combed from West to East...."74 Hitler's despised German Jews were to be a priority in this roundup, apparently because of a "housing problem and other sociopolitical considerations." 75 Those Jews caught in the Nazis' nets were to be transported by 
train, thus drawing on Eichmann's strengths, and held in a small number of centralized concentration camps. Upon arrival at these camps, prisoners would undergo a selection process to identify those capable of productive labor. Those selected would go on to help strengthen Nazi Germany's economy and military capability.

According to Friedländer, Heydrich noted, "The evacuated Jews would be assigned to heavy forced labor (like the building of roads), which naturally would greatly reduce their numbers. The remnants, 'the strongest elements of the race and the nucleus of its revival,' would have to be 'treated accordingly." 76 Presumably, the Jews assigned to hard labor would receive an insufficient quantity of food, which would ensure that a normally innocuous task like road-building would greatly weaken them and perhaps even prove lethal. Heydrich, who was alluding to Organization Schmelt's earlier use and abuse of slave labor to construct the Autobahn in the East, ${ }^{77}$ euphemistically termed this process "natural diminution."78 When no longer capable of productive labor, these Jews were to be killed. Those who were killed would be replaced with new arrivals. This plan-referred to by some historians as "extermination through work" tionists" regarding the wasteful extermination of potentially useful and now sorely needed slave labor, but could also appease the "attritionists" by eventually bringing about the total extermination of the European Jews.

So how did the Nazis intend to kill those Jews no longer capable of labor? And what, at the start of this process, was to be done with those not selected for work-the old, young, and weak? According to Friedländer, Heydrich said,

decorated war veterans, invalids, and elderly Jews (from Germany and possibly some Western or Scandinavian counties) would be deported to the "old people's ghetto" in Theresienstadt (where they would die off). But what of all the others, the unmentioned vast majority of European Jewry? Heydrich's silence about their fate stated loudly that these nonworking Jews would be exterminated. The discussion that followed the RSHA chief's address clearly showed that he was well understood. ${ }^{80}$

Some evidence, however, suggests that apparent attendee "silence" to and "understanding" of Heydrich's speech might more accurately be described by words like "curiosity" and even "skepticism." For example, 
according to Cesarani, during Eichmann's 1961 trial in Jerusalem, he confirmed that at Wannsee, "there had been blunt talk about killing methods in the second, informal half of the meeting." 81 If true (and Eichmann obviously stood to gain nothing by mentioning such things at his trial), perhaps this explains the presence of the relatively lowly and out-of-place Rudolf Lange. Most certainly, he was the only person present at Wannsee with expertise in the resettlement (killing) of Reich Jews sent to the East. ${ }^{82}$ In fact, Lange had been unable to attend the cancelled 9 December meeting because the previous day his services as a supervisor during the massacre of Jews in the Rumbuli and then Bikernieki Forests could not be spared. ${ }^{83}$ At the 20 January meeting, however, Lange could relay firsthand that mass shootings had, indeed, included Reich Jews (recall his run-in with Jeckeln) - mostly the elderly, women, and children. Perhaps Lange had been carefully selected as an invitee among the Wannsee elite because, unlike the most proven practitioners of mass shootings, the callous-mouthed Jeckeln or the ex-tradesman Karl Jäger, Lange was a jurist with all the accouterments that accompanied a person with a Ph.D. in Law. That is, Lange was much more likely to possess an air of sophistication, which might aid in taking the sharp edge off the barbaric topic under consideration.

Either way, Lange could have at least explained to the others first hand that, although there had been problems, since June 1941 hundreds of thousands of unwanted Jews had been shot. ${ }^{84}$ Furthermore, when this method faltered, as it had when the shooting squads were faced with orders to kill Western Jews, Lange could have mentioned the recent arrival of gas vans in Riga, ${ }^{85}$ or Heydrich could have chipped in by referring to the new gassing facilities at Auschwitz and Chełmno. Again, Heydrich knew about Organization Schmelt and it is interesting to note that since mid-November 1941 Schmelt had been sending exhausted road workers to Auschwitz to be gassed in Crematorium I. ${ }^{86}$ As Heydrich said at Wannsee, "even now practical experience is being gathered that is of major significance in view of the coming Final Solution of the Jewish Question."87 Eichmann was involved in the decision to send gas vans to Riga ${ }^{88}$ and had visited Chełmno in January, ${ }^{89}$ or perhaps earlier in December. ${ }^{90}$ He had been instructed by Gestapo chief Heinrich Müller to observe, as Eichmann put it, "what was going on there." 91 So it is possible Eichmann also weighed in on the conversation. What became clear at Wannsee, then, was that the Nazis were rapidly moving in the direction of a more perfect "one best way" formula 
of extermination that made provisions for the most useful Jews to make a brief contribution to strengthening Nazi Germany on their way to the grave. Representing Hans Frank, Staatssekretär Josef Bühler requested,

that the General Government would welcome it if the final solution of this problem would begin in the General Government, as, on the one hand, the question of transport there played no major role and consideration of labor supply would not hinder the course of Aktionen. [...] [This was because] of the approximately two and a half million Jews under consideration, the majority were in any case unfit for work. ${ }^{92}$

Perhaps Heydrich expected a response like this from Bühler-Heydrich was basically offering to kill anybody's unwanted Jews and, as all present would have known, nobody had more unwanted Jews than Governor Frank. ${ }^{93}$ As mentioned, Frank had long held desires of one day making his fiefdom Judenfrei.

Putting this speculation aside, Bühler's request that the Jews in the General Government should be targeted first was accepted and soon after given the code name Operation Reinhard (in fitting memory of Heydrich, who was assassinated a few months later). The Wannsee Conference eventually broke down into a debate over what to do with genetically mixed German-Aryan Jews (whom one Wannsee attendee interestingly noted would surely prefer sterilization over death, or as attendee Otto Hofmann more delicately put it "evacuation"). ${ }^{94}$ Nonetheless, Heydrich had achieved his main goals: He presented a rough outline of the latest final solution to those leading bureaucrats in the civil service agencies whose help he needed to make it a reality and, relying on his somewhat coercive and manipulative style, he obtained their consent and future compliance.

Six days after the Wannsee Conference, on 26 January 1942, Himmler signaled the relinquishment of his preferred source of slave labor when-in line with Heydrich's above plan-he informed the Inspector of Concentration Camps,

As no Russian prisoners of war can be expected in the near future, I am sending to the camps a large number of Jews who have emigrated [sic!] from Germany. Will you therefore make preparations to receive within the next four weeks 100,000 Jews and up to 50,000 Jewesses in the concentration camps. The concentration camps will be faced with great economic tasks in the coming weeks. SS-Gruppenfübrer Pohl will inform you in detail. ${ }^{95}$ 
In response to Himmler, Pohl stated in a report on 30 April 1942, "keeping prisoners on the grounds of security, re-education, or prevention was no longer a priority"; instead, the "main emphasis" had "shifted towards economics...." 96 On the same day, Pohl also informed the concentration camps that, "In order to achieve maximum performance this deployment must be exhausting in the truest sense of the word."97

With Höss's then five-month-old Zyklon-B gassing technique and Lange's activities in Chełmno probably gaining steam, Himmler did not need to worry about the potential economic burden of housing and feeding the unproductive "useless mouths" of the young, old, and exhausted in his concentration camps. Now, he could cheaply and efficiently have these Jews exterminated on arrival. Perhaps it was just a coincidence, but one month after the Wannsee Conference, the file on the Madagascar Plan was closed in favor of an alternative strategy. ${ }^{98}$ And as we shall now see, after the Lange Commando received their new gas vans in January 1942, their destructive activities indeed gained steam.

\section{Chęmno's Extermination Process: A Deadly Game of DeCEPTION}

At Chełmno, as far as Koppe knew, the Lange Commando was,

employed only on an experimental basis to begin with. This idea was based on the fact that a certain Dr. Brack, of Hitler's private chancellery, had already done some preparatory work with poison gases, and that these were to be tried out by the Sonderkommando Lange. [...] Sonderkommando Lange was the obvious choice for carrying out the gassings.... [italics added $]^{99}$

For several reasons, the Lange Commando was, as Koppe put it, the obvious choice in this new "trial and error" 100 killing experiment. First, unlike some in the Einsatzgruppen units, Lange's men had learned a few years earlier not to unload the vans themselves. Second, any "soft" members of the Lange Commando who found the vans to be disgusting, stressful, dishonorable, or inhumane had, through attrition, long ago left the T4 ranks. ${ }^{101}$ All such people had been replaced by others until eventually every position was filled by men unencumbered by such concerns. Third, the men remaining in the Lange Commando had accumulated extensive experience and had obviously become emotionally 
inured (routinized) to killing increasing varieties of "useless mouths"those with disabilities, Polish Jews, and Gypsies. This is why the Lange Commando was, as Koppe said, the "obvious choice..." But considering that many of Lange's victims would come from the Wartheland's Lódź ghetto, which, at the time, was receiving trainloads of Western and particularly German Jews, the true test would come in whether the commando could handle exterminating non-workers who dressed, sounded, and often looked much like themselves.

Across the winter months of 1941-1942, Lange's men quickly refined and then settled on a standard operating procedure. As Montague points out, the initial extermination process at Chełmno was "not fixed; there was no outlined plan to follow..." But, as the following shows, "as a result of the experience gained from each new transport..." by the cold season's end, an efficient technique of mass extermination had emerged. ${ }^{102}$ Because the victims came from all over the Wartheland, methods of transportation to Chełmno varied: trucks; trains followed by walking; trains then trucks; and eventually, trains followed by use of a narrow gauge rail line. ${ }^{103}$ Whatever the mode of transportation, Lange's men preferred breaking up the last part of the journey by detaining the victims in some kind of holding pen: A nearby synagogue, church, and an old mill were all trialed for this purpose. ${ }^{104}$ In these holding pens, Lange's men would restrict the victims' access to food, water, and sanitary facilities. This holding pen technique was purposefully designed to induce fatigue and render the victims docile to subsequent instructions. With time and increasing experience, the Lange Commando settled on a preferred holding pen: have the Jews wait under armed guard in freezing conditions in the courtyard outside the purposefully bright and inviting Chełmno castle. ${ }^{105}$ When the Jews were sufficiently desperate for shelter, camp guard Kurt Möbius describes what happened next:

[T]hey waited some time in the courtyard. Then Plate or I addressed them. We told them that they were to be sent to Austria to a large assembly camp, where they would have to work. But, it was explained to them, they would first have to take a bath and have their clothes deloused. We told the Jews this so that they would not know what fate awaited them, and to encourage them to obey calmly the instructions that they were given. After this the Jews-men, women, and children-were taken to the ground floor of the castle. ${ }^{106}$ 
This purposefully polite speech was actually delivered by a variety of Lange's men, one of whom, the previously mentioned Walter Burmeister, occasionally wore a physician's white coat to bolster the guise that Chełmno was indeed a medical-type delousing facility. ${ }^{107}$ German-speaking members of Lange's Polish work commando aided with translation. ${ }^{108}$ To draw the freezing victims a little further into the net, the castle's ground floor was purposefully kept warm. ${ }^{109}$ According to Burmeister, during the next part of the process,

New arrivals undressed in the hall $[\ldots]$ Their valuables and money were collected by Poles from the work detail. The Poles also wrote down the names, but that was only for form's sake. [...] When the Jews had undressed, they were ordered to go down the stairs and into the cellar. [...] signs hung bearing the words: 'To the Baths.' [...] From the cellar, the naked people continued straight on, leaving the building by a rear door and going up onto a wooden ramp. One of the gas vans...was backed up to the end of the ramp with the doors open. [...] The people who came out of the cellar by the rear door did not have any choice but to climb into the van. As soon as the interior was full...the door was closed. ${ }^{110}$

Again, according to Möbius,

Most of the Jews got into the gas van calmly and obediently, trusting in the promises made to them. The Polish workers accompanied them. They carried leather whips with which they struck obstinate Jews who had become mistrustful and who hesitated to go further. ${ }^{111}$

Another guard, Theodor Malzmüller, provides more detail about this part of the process:

The Jews were made to get inside the van. The job was done by three Poles, who I believe were sentenced to death. ${ }^{112}$ The Poles hit the Jews with whips if they did not get into the gas-van fast enough. When all the Jews were inside the door was bolted. The driver then switched on the engine, crawled under the van and connected a pipe from the exhaust to the inside of the van. ${ }^{113}$

According to commando member Wilhelm Heukelbach, "Soon screams and groans could be heard coming from the interior. Those inside were hammering on the sides of the van." "14 The initial protocol was to drive 
the vans out of the castle grounds to the burial site in the Maiden forest several kilometers away, thus killing the victims on route. But vans loaded with screaming victims passing through Chełmno's village streets detracted from Lange's desire that the local (Gentile) community remain unaware of his tasks. ${ }^{115}$ Consequently, Lange's men had to adopt a less time-efficient protocol: The vans remained within the castle compound in a stationary position - for about 10 minutes or $\mathrm{so}^{116}$ — until all the victims were dead. From the time the victims arrived at Chelmno to the time they entered the gas vans, no more than one-and-a-half hours had elapsed. ${ }^{117}$ The vans loaded with dead bodies were then driven from the castle to the forest. Hauptscharführer Gustav Laabs describes what happened during his first driving mission:

After about three kilometers we arrived in a clearing in the wooded area that runs alongside the road to Warthbrücken. In the clearing the officer told me to stop in front of a mass grave, where a work detail of Jews was working under the supervision of a police officer. There were also several policemen spread out in a circle, who were obviously on sentry duty. The police officer supervising the work detail ordered me to back the van up to the mass grave. ${ }^{118}$

According to Jacob W., a non-commissioned police officer, the clearing in the forest contained several mass graves shaped like large swimming pools, each about three meters deep. Two particularly large graves measured about thirty meters long and ten meters wide. ${ }^{119}$ Across the winter of 1941/1942, these graves were dug using pickaxes and shovels. ${ }^{120}$ From the spring onward, however, more efficient digging machinery was introduced. ${ }^{121}$ One of the mechanically dug graves ended up being 254 meters long(!) ${ }^{122}$ Laabs continues,

Then the policeman who had driven in the cab with me undid the padlock that fastened the doors. A few members of the work detail were ordered to open the double doors. Eight or ten corpses fell to the ground, and the rest were thrown out of the back by the members of the work detail. ${ }^{123}$

After all the victims' gold teeth had been extracted, ${ }^{124}$ their bodies were dumped in the graves and left to rot. Because the graves in the wintery conditions took so long to excavate, maximized utilization of this limited space was achieved by having the victims' bodies stacked facedown and 
head-to-toe. ${ }^{125}$ Initially, the Polish collaborators performed all of these grisly and arduous tasks, but, perhaps as a reward for their loyalty, with time Jewish work commandos were set up and performed most of this labor. Thereafter, the Poles moved on to other (relatively) more attractive roles: van maintenance; collecting and sorting clothing, valuables, and luggage; and even occasionally driving the vans. ${ }^{126}$ In terms of role allocation, much like during the mass shootings, all the worst-arduous, stressful, and/or repulsive-jobs were assigned to some subordinate category of non-German.

If members of the Jewish work detail were unwilling or unable to perform their frightful roles, they were shot. According to a non-commissioned officer by the name of Josef I,

Almost every day members of the Jewish work detail were shot in the forest camp, in the evening before the commandos returned to Kulmhof [Chełmno]. They were always Jews who were unfit for work or who refused to work. Most of the time five or six were killed, but sometimes as many as ten people were shot. The executions were mostly carried out by Polizeimeister Lenz. He ordered the Jews to lie face down on the edge of the mass grave. Then he took his pistol and shot them in the back of the neck. The other Jews then had to throw the bodies into the mass grave. ${ }^{127}$

Working in the Jewish work commando was undoubtedly a nightmare beyond imagination, and it is not surprising that many chose death over the offer to work and live a little longer.

After establishing the above standard operating procedure across the winter of 1941-1942, in March 1942 the "ironfist[ed]" Lange was transferred to the RSHA head office in Berlin and was replaced by the more "easygoing" commandant Hans Bothmann. ${ }^{128}$ Easygoing or not, Lange's set procedure under Bothmann's supervision saw Chełmno continue to consume large numbers of Jewish lives. More specifically, it has been estimated that one cycle of the killing process at Chełmno could, depending on the size of the van used, kill between 35 and 170 civilians. ${ }^{129}$ According to Möbius, one cycle could be performed "five to eight, sometimes even ten times a day" and, depending on the influx of Jews, do so potentially six days a week. ${ }^{130}$ Obviously, Chełmno was never intended to single-handedly offer a solution to the Nazi's Europeanwide "Jewish question." Chełmno started out as an experiment to resolve a local problem - a pilot study that aimed to eliminate all the 
"useless mouths" in the Lódź ghetto, thereby making room for influxes of Western Jews. ${ }^{131}$ And unlike Lange's earlier experimental foray with slacked lime, the Chełmno pilot proved successful in achieving its goal. Between 16 January and 2 April 1942, 44,064 Jews from the Łódź ghetto were murdered in Chełmno. ${ }^{132}$

Two weeks later, on 16 April 1942, Himmler, after meeting with Hitler, flew into Poznań and met with Greiser and Koppe. What could they possibly have talked about? The following day Himmler, Koppe, and possibly Greiser met with some Baltic German settlers in the township of Koło (whose entire Jewish population, it will be recalled, had been exterminated in Chełmno several months earlier). ${ }^{133}$ It is not known if Himmler visited the nearby castle, but he did order that 10,000 Western Jews in the Łódź ghetto (originally from Germany, Austria, Czechoslovakia, and Luxemburg) be killed next. Four weeks later, his orders had been converted into a reality. ${ }^{134}$ This was the first largescale mass gassing of Western Jews. ${ }^{135}$ As Montague notes, by "May 15, only 31 percent of these Western European Jews, who had arrived only some six months earlier, remained in the ghetto." 136 Killing the difficult-to-shoot Reich Jews-men, women, and children-who dressed, sounded, and often looked much like the Germans themselves obviously posed no problem for Lange's men. In fact, no matter what category of victim-whether they be mentally ill, Eastern Jews, Gypsies, Western Jews-Lange's gassing commando, eventually under Bothmann's management, never seemed to complain about any "burdening of the soul." A leader from Berlin just need to point his finger in a certain direction, and soon after all in that direction were dead.

The closest the Germans working at Chełmno came to encountering a major problem was when spring arrived. That is, the victims' bodies started decomposing and bodily fluids started spilling out of the mass graves. The putrid stench that filled the air proved so powerful that on 11 June 1942, Chełmno stopped accepting further transports. ${ }^{137}$ The remains in the graves needed to be cremated. Independent of this problem, in March 1942 Himmler had already tasked the mentally fragile but nonetheless determined Paul Blobel with discovering the most efficient and effective techniques of mass cremation. ${ }^{138} \mathrm{He}$ did this because as the snow on the Eastern front started to thaw, it was feared that an advancing Red Army might discover mass graves filled with Soviet POWs and civilians. Even worse, what if the Wehrmacht's up-and-coming counteroffensive failed and Germany ended up losing the war? Facing such 
possibilities, a less confident Himmler realized that his days of acting with impunity might be numbered. ${ }^{139}$ Consequently, Blobel's goal was to erase all evidence of the Nazi's genocidal past. ${ }^{140}$ His first assignment was the recently closed Chełmno camp where in the summer of 1942 he assembled a large group of Jewish workers known as Kommando 1005. Kommando 1005 set about exhuming, then cremating, the remains of the extermination camp victims in massive outdoor bonfires. ${ }^{141}$ During Blobel's stay at Chełmno, he too used trial-and-error techniques of discovery until his team settled on the most efficient and effective techniques of mass cremation. ${ }^{142}$

Once Blobel's men got on top of the body disposal problem, Bothmann's commando was able to get back to what they did best. With several vans used across the score of months that Chetmno was open, the number of victims quickly added up. Information from a 1962 trial at Bonn has shown that between December 1941 and July 1944 at least 153,000 people for whom documentation existed were killed in the gas vans at Chełmno. ${ }^{143}$ Having said this, because documentation did not always exist, according to Montague the actual victim count was "no doubt" higher. ${ }^{144}$ Despite this massive number and as a dark sign of things to come, Chełmno was just the first of what Hilberg terms the most "primitive" of the Nazi extermination centers. ${ }^{145}$ Despite its (relatively) primitive nature, the camp at Chełmno was thorough-of all the civilians sent its way, only seven managed to escape. ${ }^{146}$ In the end, Chełmno saw the alignment of a number of factors that foreshadowed the success of mass killing on a much larger scale: a cheap/mobile gas, an industrialized assembly-line organizational process, centralization (where mobile victims were delivered to a stationary execution plant), and a hardened and professionally trained pool of specialist executioners. Therefore, on all fronts, Chełmno, as a small-scale experiment, glowed with immense killing potential. All that was needed were ideas likely to improve overall systemic efficiency, increase its scale, and finally replicate the number of such facilities. Elsewhere other more ambitious project managers were doing just this.

\section{The Emergence of Operation Reinhard}

More than three months before the Wannsee Conference and just as Lange was receiving instructions to kill Jews in the Wartheland, on 13 October 1941, ${ }^{147}$ Odilo Globocnik suggested to Himmler ${ }^{148}$ that 
the General Government should be "Germanized" by killing the local Jews. ${ }^{149}$ More specifically, Globocnik envisioned that killing off some local Jews in the General Government would help relieve the food supply problem, stem black market activity, and free up accommodation for newcomers, ${ }^{150}$ particularly for inbound Slovakian and Reich Jews. ${ }^{151}$ Himmler thus approved Globocnik's construction of a death camp in the General Government. ${ }^{152}$ Perhaps the failure of Globocnik's own men around this point in time to find a more "humane" method of killing local Jews (using grenades) explains why, as the following shows, he was eventually sent the civilian-killing specialists who, after being "employed only on an experimental basis," might prove more capable of Germanizing the General Government.

Viktor Brack, a former member of the disbanded T4 team, stated in his postwar testimony,

In 1941, I received an order to discontinue the euthanasia program. In order to retain the personnel that had been relieved of these duties and in order to be able to start a new euthanasia program after the war, Bouhler [head of the Führer Chancellery] asked me-I think after a conference with Himmler - to send this personnel to Lublin and place it at the disposal of SS Brigadefübrer Globocnik. ${ }^{153}$

In fact, as 1941 came to an end, ninety-two ex-T4 personnel were sent east by the Führer Chancellery. ${ }^{154}$ One of them, Christian Wirth, became Globocnik's top aide on 14 October $1941,{ }^{155}$ just one day after Himmler's meeting with Globocnik. ${ }^{156}$ Wirth had been present at the first-ever euthanasia gassing pilot two years earlier and then started killing people at the T4's permanent gas chamber in the Brandenburg-Havel prison. Subsequently, Wirth was employed at Hartheim, the most "efficient" of all the T4 facilities, where, according to Adam, "he distinguished himself...by his organizational abilities." 157 In December 1941, Wirth arrived in Lublin. ${ }^{158}$ Although Wirth was acquainted with the "advantages and disadvantages" of the gas vans used in the Soviet interior and at some point observed the killing process at Chełmno, ${ }^{159}$ he does not appear to have contemplated using such vehicles in the General Government. Wirth's means-to-end logic more closely resembles an extension of the kind of system he had relied upon in Germany: a permanent gas chamber facility with the more efficient capacity to dispose of bodies on-site. Also gas vans had volume and weight limitations, but a permanent gas chamber 
had no such restrictions and could-should it ever be required-potentially handle much larger numbers of victims per cycle.

On 1 November 1941, construction on Wirth's death camp-called Belzec-began. ${ }^{160}$ The center's gassing apparatus was sourced from a recently abandoned T4 euthanasia facility in Germany. ${ }^{161}$ According to Stanislaw Kozak, a Polish construction worker,

we built a third barrack, which was $12 \mathrm{~m}$. long and $8 \mathrm{~m}$. wide. This barrack was divided by wooden walls into three sections, so that each section was $4 \mathrm{~m}$. wide and $8 \mathrm{~m}$. long. These sections were $2 \mathrm{~m}$. high. The interior walls of these barracks were built such that we nailed the boards to them, filling in the empty space with sand. Inside the barrack the walls were covered with cardboard; in addition, the floors and the walls were covered with sheet zinc to a height of $1.1 \mathrm{~m} .^{162}$

The actual gassing apparatus must have taken a long time to stripe and then transport out of Germany because the construction of Belzec's gas chambers was not completed until the end of February 1942. Then, Wirth, much as Lange had a few months earlier, pursued a number of pilot studies to test, refine, and iron out the kinks of his killing process. According to SS-Unterscharführer Franz Suchomel, "Belzec was the laboratory. Wirth was camp commandant. He tried everything imaginable there."163 Again like Lange, Wirth initially used pure bottled carbon monoxide. ${ }^{164}$ These pilots were undertaken over a period of several days and involved several convoys, each consisting of about four to six freight cars of Jewish victims. ${ }^{165}$ Soon afterward, the canisters were substituted by exhaust fumes generated by a stationary 250 horsepower engine. ${ }^{166}$ After test-running the new system, the Belzec extermination center opened on 17 March 1942. Although at this point (mid-March 1942) $75-80 \%$ of eventual Holocaust victims could be counted among the living, 11 months later only $20-25 \%$ would remain alive. ${ }^{167}$

Importantly, back in the fall of 1941 when Globocnik first approached Himmler over his desire to kill local Jews by building what became the Belzec extermination center, there were no plans to build other similar and accompanying death camps in the General Government. But at some point in time after the end of 1941 (probably early 1942), Wirth became sufficiently confident in Belzec's enormous killing potential. It was only on this realization that - with much larger numbers of victims in mindlonger-term plans to build other potentially "improved" Belzec-like 
extermination camps were devised. I say this because it is unlikely the Nazi regime would invest significant sums of money into constructing such a large-scale multi-site project that, in the absence of any testing, might actually prove to be a failure. As Dieter Pohl insightfully notes, at some level a "limited capacity" version of Belzec first had to prove its worth before any "upgrading" was possible. ${ }^{168}$ And obviously the best assessor of that worth was gassing expert Wirth. In support of this, as Wirth's liaison officer, SS-Untersturmführer Josef Oberhauser said, after Belzec first opened "the gassings were not yet part of a systematic eradication action but were carried out to test and study closely the camp's capacity and the technical problems involved in carrying out a gassing." 169 Upon Belzec, as it turned out, proving its destructive worth, as Oberhauser implies, it also made sense that the new death camp would serve as the experimental prototype from which all subsequent centers-Sobibor and Treblinka-would learn and advance. ${ }^{170}$ Having said all this, Wirth must have become confident in Belzec's enormous killing potential just before or as the camp opened in, as just mentioned, mid-March 1942, because construction at Sobibor started sometime during the same month. ${ }^{171}$

Anyway, Wirth's observations of Belzec in action led to his recommendation that Sobibor be built on a larger section of land. More space at Sobibor meant, for example, that unlike at Belzec, more than a maximum of twenty train carriages at a time could enter the camp ${ }^{172}$ and that confiscated property could more efficiently be stored on-site. It also meant at Sobibor a potentially longer path separating the undressing area from the gas chambers could be built (presumably better ensuring those victims undressing were less likely to hear the screams of those ahead of them in the process being gassed). ${ }^{173}$ Wirth's biggest concern, however, was that frequent usage of Belzec's wooden gas chambers might fail to resist the internal pressures generated by the collective force of large groups of panicking victims. ${ }^{174}$ It was therefore decided that Sobibor's gas chambers should be made from brick rather than wood. The newer and improved Sobibor extermination center, which opened in May 1942, was to be managed by ex-T4 employee Franz Stangl, whom Globocnik apparently believed to be "a good organizer...." 175 The initial chambers at Belzec and Sobibor were capable of killing approximately 150-200 and 140-160 people per gassing, respectively ${ }^{176}$ - a task that could be performed several times a day. ${ }^{177}$ 
In mid-June 1942, Wirth suspended operations at Belzec so the wooden chamber could be replaced with a structurally stronger facility. ${ }^{178}$ This suspension signaled the end of Belzec's first stage. In its three months in operation, nearly 100,000 Jews were killed. ${ }^{179}$ Clearly, Belzec was a far superior killing facility to Chełmno (which at its peak efficiency took twice as long to kill the same number of people). ${ }^{180} \mathrm{~A}$ month later, Himmler visited Globocnik at Operation Reinhard's headquarters in Lublin, presumably to receive a detailed progress report. By this time, Globocnik was armed with data about Belzec and Sobibor's killing capacity, the latter of which Himmler apparently visited that day. ${ }^{181}$ Like Belzec, Sobibor had killed 90,000-100,000 Jews in its first three months of operation. ${ }^{182}$ A few days later on 19 July 1942, after some meetings with Hitler, Himmler issued the staff of Operation Reinhard an end-ofyear deadline.

I herewith order that the resettlement of the entire Jewish population of the General Government be carried out and completed by December 31, 1942. From December 31, 1942, no persons of Jewish origin may remain within the General Government, unless they are in the collection camps in Warsaw, Cracow, Czestochowa, Radom, and Lublin. All other work on which Jewish labor is employed must be finished by that date, or, in the event that this is not possible, it must be transferred to one of the collection camps. ${ }^{183}$

It was during this month-July 1942-that Himmler apparently informed his personal masseuse, Felix Kersten, that his present work would end in "the greatest piece of colonization which the world will ever have seen." 184 Around this time, the prospective German beneficiaries of Himmler's colonial ambitions invested, as perhaps best captured by Götz Aly, great hope in his success: "By 1942 German children were staging imaginary gunfights on the 'black soil' of central Russia, while hundreds of thousands of soldiers' wives dreamed of owning country estates in Ukraine." 185 German authors Thea Haupt and Ilse Mau soon contemplated the writing of a primer designed to "acquaint small children with the ideas behind the settlement plan and transfer the cowboys-and-Indians romanticisms [of the American West] to Eastern Europe. $" 186$

A week or so after Himmler delivered his end-of-year deadline, Treblinka, the third and most "perfect" of Wirth's three extermination 
centers, was completed. ${ }^{187}$ This center was to be managed by another ex-T4 employee, Irmfried Eberl, a medical doctor who was also present at the euthanasia gassing pilot. According to Unterscharführer August Hingst, who worked at Treblinka, Eberl's ambition, somewhat like that of the highly competitive Jeckeln, was to kill as many people as possible, and certainly more than the other two centers. ${ }^{188}$ Eberl's strategy to achieve this goal seems to have been to solicit and accept more victims than both Wirth at Belzec and Stangl at Sobibor, to have the gas chambers running almost continuously, to dump the bodies in mass graves dug mechanically by an industrial scoop shovel, and, finally, to simply hope the center's staff and facilities were able to sustain a frightfully high rate of killing. Eberl boldly accepted 312,500 potential victims in Treblinka's first five weeks of operation. ${ }^{189}$ However, as Eberl discovered, although Treblinka was the most "perfect" of the three Operation Reinhard facilities, it was not absolutely perfect. The commandant's ambitions exceeded the extermination center's ability to absorb such massive numbers of civilians, and a backlog of freight cars crammed with Jews started to accumulate outside the camp gates. With no access to water, many of the Jews simply perished in the intense summer heat.

Simultaneously, the high summer temperatures also started to cause problems at Sobibor and Belzec. Much like at Chełmno, the recently buried bodies started to bloat, causing the thin surfaces of the camps' mass graves to burst open. Sobibor worker Leon Feldhendler described the scene. "After gassing, the people were laid into the graves. Then, out of the soil, blood and bad odor of gas began to surface; terrible smells spread over the whole camp, penetrating everything. The water in Sobibor became rancid." 190 Blobel's recent discoveries of the most effective mass outdoor cremation techniques were passed on to Globocnik, who introduced them to all three of the Operation Reinhard camps. ${ }^{191}$ For example, according to Feldhendler, at Sobibor a large pit was dug "with a roaster above it. The bodies were thrown on the roaster. The fire was ignited from beneath, and petrol was poured on the corpses. The bones were crushed into ashes with hammers..." 192 Burning so many bodies, however, was a time-consuming task that generated a major bottleneck in the otherwise smooth-flowing system. The rate of killing declined. As all other camps would soon discover, maximum killing capacity greatly exceeded the on-site ability to both efficiently and hygienically dispose of victims' bodies. 
Eberl at Treblinka, however, was unwilling to slow down, and chaos soon reined throughout the camp. Before long, the extermination center's tight security measures deteriorated to the point where escapes became common. ${ }^{193}$ These security breaches quickly attracted the attention of Globocnik and Wirth who, upon seeing the camp in disarray, dismissed the overly ambitious Eberl. Eberl was replaced with the more reliable Stangl (while Franz Reichleitner, another ex-T4 employee, took over at the smaller Sobibor center). Even so, the $210,000^{194}$ or $280,000^{195}$ lives Treblinka extinguished in just its first five weeks of operation meant the latest Nazi extermination center had flexed its genocidal muscle. ${ }^{196}$ Eberl was not exaggerating when he earlier wrote in a letter to his wife, "The pace in Treblinka is truly breathtaking." 197 As survivor Abraham Krzepicki put it, the mass slaughter at Treblinka resembled "A factory of horror whose sole product was bodies." 198

Nevertheless, the problems at Belzec, Sobibor, and Treblinka put Himmler's end-of-year deadline in jeopardy. Globocnik and Wirth were aware that, just like at Belzec, the killing capacity of the gas chambers at both Sobibor and Treblinka had to be increased. Consequently, they needed to build additional or completely new and much larger gas chambers. Plans to expand, however, generated new problems that also threatened the achievement of Himmler's deadline. Larger chambers at Belzec and Sobibor had to be filled with sufficiently lethal quantities of exhaust fumes. This not only meant increased fuel costs but also that victims would take longer to die. The new and much larger gas chambers could, therefore, generate financial and temporal inefficiencies. At Treblinka, however, the cumulative improvements that often come with the application of goal-directed means-to-end rationality saw the elimination of these problems with a single innovation. There, simply lowering the ceiling height of the new set of gas chambers by $60 \mathrm{~cm}$ both increased killing efficiency and lowered fuel costs. With less space to fill with sufficiently lethal concentrations of exhaust fumes, this innovation reduced the asphyxiation time and thus decreased the amount of time before bodies could be removed. ${ }^{199}$ The three camps' new and larger gas chambers all produced massive increases in killing efficiency. According to Yitzhak Arad, the number of victims per gassing in the new chambers at Belzec and Sobibor doubled. At Treblinka, it may have quadrupled (Table 6.1). ${ }^{200}$

At his trial following the war, Franz Stangl admitted, when asked about the second period of exterminations at Treblinka, that, "the 


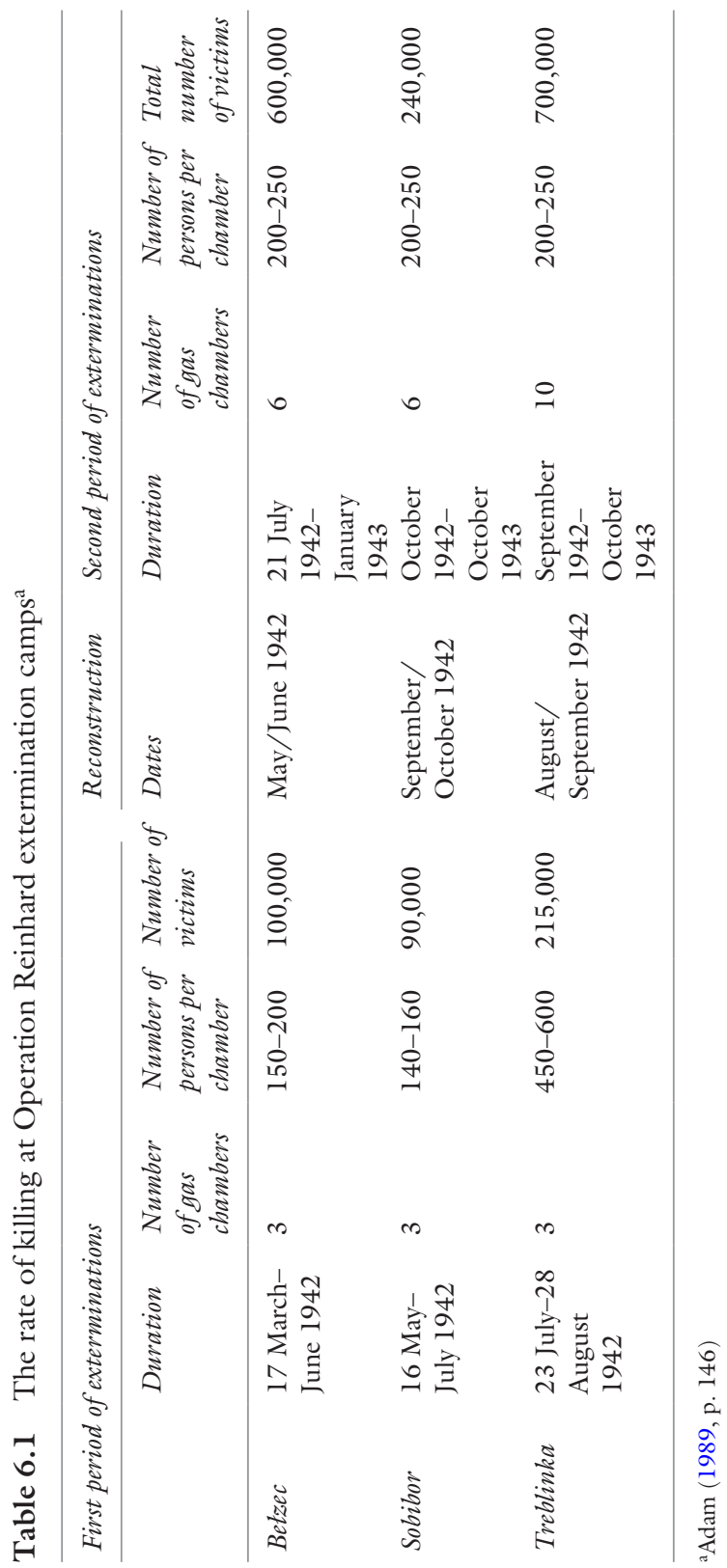


optimum amount of people gassed in one day, I can state: according to my estimation a transport of thirty freight cars with 3,000 people was liquidated in three hours. When the work lasted for about fourteen hours, 12,000 to 15,000 people were annihilated."201

Operation Reinhard not only met Himmler's end-of-year deadline by exterminating all the Jews in the General Government, ${ }^{202}$ but was also expanded to include the Jews of Bialystok and the Ostland. ${ }^{203}$ On 12 February 1943, Himmler once again visited Sobibor. ${ }^{204}$ One month later, on 13 April 1943, Globocnik successfully pushed for Wirth to be promoted to SS-Sturmbannführer or Major. ${ }^{205}$ At the end of Operation Reinhard in late October 1943, 1,500,000-1,700,000 Jews had been murdered. ${ }^{206}$ Approximately 600,000 were killed at Belzec, ${ }^{207} 250,000$ at Sobibor, ${ }^{208}$ and between 700,000 and 800,000 at Treblinka. ${ }^{209}$ Operation Reinhard also proved highly profitable: After deportation and extermination costs, it has conservatively been estimated that almost 179 million Reichsmarks were diverted into the Nazi coffers ${ }^{210}$ - money then pumped into the Nazi war machine. ${ }^{211}$ And unlike the labor-intensive mass shootings, "these three huge extermination factories in which approximately one-third of all Nazi genocide victims were murdered, were never operated by more than a little over 100 German camp officials." 212 Belzec, for example, required several hundred worker Jews, a hundred or so Ukrainians, and just 20 Germans (many in distant managerial roles). ${ }^{213}$ Such efficiency depended greatly on the total compliance of the victims themselves. A closer look at Belzec's standard operating procedure reveals how the compliance of most victims was secured.

On 19 August 1942, hygienist professor Wilhelm Pfannenstiel of the SS, armed with a stopwatch, observed Belzec's carefully organized killing process:

After they had undressed, the whole procedure went fairly quickly. They ran naked from the hut through a hedge into the actual extermination centre. The whole extermination centre looked just like a normal delousing institution. In front of the building there were pots of geraniums and a sign saying 'Hackenholt Foundation', above which there was a Star of David. The building was brightly and pleasantly painted so as not to suggest that people would be killed here. From what I saw, I do not believe that the people who had just arrived had any idea of what would happen to them. Inside the building, the Jews had to enter chambers into which was channeled the exhaust of a [100(?)]-HP engine, located in the same building. ${ }^{214}$ 
According to survivor Rudolf Reder, two Russian staff members operated the engine. ${ }^{215}$ In Pfannenstiel's view, once locked in, "it was only then that the people sensed something else was in store for them. It seemed to me that behind the thick walls and door they were praying and shouting for help. After about twelve minutes it became silent in the chambers."216 In another account, Pfannenstiel stated it took eighteen minutes for the victims to die. Whether it was twelve or eighteen minutes, he still "found it especially cruel" that it took so long. ${ }^{217}$ Whether by accident or design, Pfannenstiel believed that the gas chambers' new strain resolving "thick" concrete walls helped muffle (reduce) the intensity of the victims' screams. Before the victims were removed and cremated, a Jewish work detail stripped the bodies of anything of potential value, particularly gold teeth and any hidden valuables.

To encourage the victims at Belzec to enter the gas chambers of their own accord, the perpetrators relied on certain tried-and-tested tricks of deception, including the installation of fake showerheads (as at the T4 institutions) and promising the victims work on the condition that they undergo delousing (as at Chełmno). With its pleasantly painted buildings and strategically placed geranium pots designed to alleviate victims' fears that they had arrived at a death camp, Belzec also developed some of its own techniques of deception. As survivor Ada Lichtman notes, similar tricks were used at both Sobibor and Treblinka:

We heard word for word how SS-Oberscharführer Michel, standing on a small table, convincingly calmed the people; he promised them that after the bath they would get back all their possessions, and he said that the time had come for Jews to become productive members of society. They would presently all be sent to the Ukraine, where they would be able to live and work. The speech inspired confidence and enthusiasm among the people. They applauded spontaneously, and occasionally they even danced and sang. ${ }^{218}$

One survivor observed that at Sobibor this speech was, much like at Chełmno, delivered by a German wearing the white coat of a medical doctor. ${ }^{219}$ Another technique of deception was that after arriving, some victims were coerced into writing postcards to their relatives, informing them of the apparently auspicious outcome of their journey to the East: They said the Germans treated them well and there was food, shelter, and employment. ${ }^{220}$ Obviously, all these tricks were designed to ensure an unencumbered flow of docile victims into the camps. 
Some of those Jews lucky enough to escape returned to the ghettos to warn others of the impending danger. Word soon spread, and for those Jews forcibly transferred by train to unknown destinations, words like "Belzec," "Sobibor," and especially "Treblinka" became signals of imminent death. Increasingly, Jews arriving at the extermination centers were no longer easily duped by the "showers" or the promises of work. Growing numbers of victims refused to comply with their executioners' requests and some engaged in spontaneous acts of resistance. Probably, the earliest significant and verified act of resistance occurred at Treblinka. In the second week of December 1942, a group of youths from the Kelbasin camp refused to enter the gas chambers. With fists, knives, and even a grenade, they resisted. A riot ensued, but with superior firepower the guards rapidly quelled the resisters, resulting in massive carnage. ${ }^{221}$

Wirth and Stangl feared such resistance because it not only endangered their own lives but also removed a key ingredient that enabled them to inflict death on such a massive scale-victim docility. Sharing much in common with Jeckeln's shooting process, the gassing operations from start to finish required that victims remain totally compliant, because any resistance would create bottlenecks in the system, ${ }^{222}$ which would threaten the achievement of Himmler's ambitious goals and tight deadlines. In Ritzer's terminology, victim docility provided the Germans with greater "control" over the flow of the process, which enhanced "predictability," whereby it became possible to anticipate the weekly output of bodies. As the ability to predict increased, "calculability" became possible, allowing managers like Himmler to set ambitious, but not unrealistic, production targets by calculating the output of bodies expected over a certain number of weeks. And to achieve Himmler's targets, every week a certain minimum number of people needed to be killed. ${ }^{223}$ Just two weeks after the revolt at Treblinka, Stangl introduced more sophisticated techniques of deception in order to reinstate the essential ingredient of victim docility.

AT CHRISTMAS 1942 Stangl ordered the construction of the fake railway station. A clock (with painted numerals and hands which never moved, but no one was thought likely to notice this), ticket-windows, various timetables and arrows indicating train connections 'To Warsaw, 'To Wolwonoce,' and 'To Bialystock' were painted on to the façade of the 'sorting barracks'; all for the purpose of lulling the arriving transports - an increasing number of whom were to be from the West - into a belief that they had arrived in a genuine transit camp. ${ }^{224}$ 
Another technique of deception appeared just 40 meters from the gas chambers where,

a small musical ensemble stood under a tree. Three Jews with yellow patches, three musicians from Stock, stood and played there on their instruments. [...] They played enthusiastically. It was difficult to make out their repertoire...these were apparently the latest hit songs favored by the Germans and Ukrainians. ${ }^{225}$

Much like the pleasant pots of geraniums, this cheerful ensemble suggested anything but a death camp. However, it seems the main purpose of the music was to "drown out the victims' screams on their way to the gas chambers...so that they would not be heard throughout the camp...."226 An orchestra was also present at Sobibor, ${ }^{227}$ where, according to survivor Mirjam Penha-Blits, the latest musical hits could be heard "blasting out..." of loudspeakers. ${ }^{228}$

Just how successful these deceptions were is unclear. What is clear is that they served to intensify the concerns of members of the camps' Jewish work details, who were ever mindful of their precarious existence. With more time than new arrivals to plot, plan, arm, and identify weaknesses within the system, it was working Jews who posed the greatest threat to Operation Reinhard. Two major revolts instigated by Jewish underground organizations ended in escapes. The first occurred on 2 August 1943 at Treblinka, which facilitated the escape of a small number of prisoners and the deaths of many. Half-a-month later, on 19 August 1943, Treblinka was closed. ${ }^{229}$ The second major revolt occurred at Sobibor on 14 October 1943 and ended in significant staff casualties and many escapes. ${ }^{230}$ Along with meticulous planning and near-perfect execution, a major contributing factor to the success of this revolt was that German staff broke an all-important camp rule. As Richard Glazor, one of the escapees, explained,

The idea [to revolt] was almost ripe back in November 1942. Beginning in November '42, we'd noticed...that we were being "spared," in quotes. We noticed it and we also learned that Stangl [sic Franz Reichleitner], the commandant, wanted, for efficiency's sake, to hang on to men who were already trained specialists in the various jobs: sorters, corpse haulers, barbers who cut the women's hair, and so on. This in fact is what later gave us the chance to prepare, to organize the uprising. ${ }^{231}$ 
At other camps, Jewish workers were periodically executed and replaced with new workers as per instructions, thus reducing the risk of revolt. But at Sobibor this rule was ignored. Five days after this successful revolt, on 19 October 1943, it was decided to close and dismantle Operation Reinhard, which had already achieved both its original and most of its new objectives. ${ }^{232}$

This somewhat premature shutdown, however, left a few tasks remaining. How, for example, was Himmler to erase the last official trace of Jews in the General Government, who, due to their better physical condition, had been selected to work in various commercial and military enterprises (the majority of whom were at the Majdanek, Poniatowa, and Trawniki labor camps)? Himmler moved quickly and with stealth because if these surviving Jews caught wind of the successful revolt at Sobibor, it was feared they might be inspired to act similarly. ${ }^{233}$ Without industrial-sized gas chambers to do his dirty work, the safest option was to have these workers shot. With the help of SS and Police Leader Friedrich-Wilhelm Krüger, Himmler hatched Operation Harvest Festival (or Erntefest). The first stage of this operation involved instructing management at all three labor camps to have their prisoners dig zigzag trenches in fields close to the camp boundaries (ostensibly for defensive military purposes). Then, on 3 November 1943, several thousand police and SS men simultaneously surrounded the camps. Using Jeckeln's Babi Yar model, over the next two days the Jews were stripped of their clothes and forced toward the trenches through heavily armed cordons of police and SS men. Then, they were systematically shot in the trenches. The victims who followed were to stack themselves like sardines on top of those shot before them. By the end of the second day, 43,000 Jews had been shot in the largest mass shooting of civilians undertaken by Germans during World War Two. ${ }^{234}$ Arad explains what happened next at Trawniki.

A group of 100-120 Jews from the Milejow camp (east of Lublin) were brought to cremate the corpses of the murdered. After two or three weeks, when they finished the cremating work, they were also shot. They were shot in small groups, and each group had to cremate the corpses of the previous group. The last group was cremated by the Ukrainian guards. ${ }^{235}$

The men of Reserve Police Battalion 101 participated in Operation Harvest Festival. However, these "ordinary" Germans only performed 
cordon and transport duties. ${ }^{236}$ For a big job like "Majdanek and Poniatowa during Erntefest, the Security Police of Lublin furnished the shooters." These ordinary yet no doubt capable Germans, having risen to the top of Himmler's attrition process, were, according to Browning, killing "specialists."237

\section{Conclusion}

This chapter traces a "rational" journey in mass murder that started out as pilot studies and rapidly expanded into a carefully calculated, continuously improving, and ultimately successful attempt to murder all the "useless mouths" in the General Government. Between late 1941 and mid-1942, a journey of discovery took place among a competitive group of specialists that generated rapid advances across all four components of a rationalized system: increased control, calculability, predictability, and efficiency (along with a movement from human to more non-human technology). That is, after gradually developing a standardized set of mostly non-human cordon/security measures-sealed, electrified, and barb-wired perimeters, minefield buffer zones, 24 hour armed security towers, regular Jewish worker rotations-and relying on a variety of equally controlling techniques of deception, eventually one innovator-Christian Wirth-managed to invent a virtually inescapable and highly efficient assembly-line process of mass murder. The key to the success of Wirth's veritable factory of death was the uncanny ability of his system to efficiently convert a constant, calculable, and therefore predictable flow of docile victims into dead bodies.

Wirth's journey of discovery shares much in common with Jeckeln's. Much like the shooting campaign, the "twisted road" from Lange's gas vans through to the construction of the Treblinka extermination camp exhibited initially low rates of killing, top-down pressure to increase those rates, the application of formal rationality from the bottom-up (increased experimentation, bureaucratization, and the honing of a less stressful industrialized killing process), resulting in increased kill rates that only served to stimulate new top-down pressures to kill more Jewsthus occasioning an ever-expanding cycle of destruction. A key commonality between both murder campaigns was an interactive relationship between top-down and bottom-up forces whereby, as Matthäus observes, "[n] ot only did those committing mass murder learn by doing, but their top commanders and those in planning positions learned as well." 238 
The key distinguishing feature separating the murder campaigns was that Wirth's "one best way" of killing civilians was more successful than Jeckeln's largely because Wirth developed a more impersonal, less public, less labor intensive, and more industrial and organized means of mass extermination. Consequently, unlike the shooting squads who balked over killing certain types of victims, Wirth and his fellow ex-T4 gassing experts revealed an uncanny and unparalleled knack for killing without complaint any civilians sent their way: Gypsies, Reich Jews, the elderly, women, children, even babies. When Wirth scaled all the weighty psychological obstacles associated with killing civilians and refined his frightfully efficient killing process, he toppled Jeckeln from his star innovator role in Nazi Jewish policy. Wirth became the solution to the Nazi regime's seemingly unresolvable and expanding "Jewish problem."

But in the Nazis' competitive bureaucracy where entrepreneurial functionaries constantly tried to outdo one another, Wirth's elevated status did not last long. Operation Reinhard gassing factories were only designed to exterminate people unable to work. Few of these victims were lined up as working fodder for the German war effort or broader economy. However, as discussed at the Wannsee Conference, for all the other Jews in Western and Central Europe who had not experienced the starvation conditions endured by those entrapped in the Polish ghettos, the Nazis' flagging military fortunes meant that a camp of dual purpose-elimination through work and, for non-workers, immediate extermination-was now needed. This more productive, yet still highly destructive work and death camp would become the new most "perfect" solution. It was called Auschwitz-Birkenau. Destruction with far greater efficiency was about to be perfected.

\section{Notes}

1. Lifton (1986, p. 89).

2. Evans $(2004$, p. 17).

3. Adam (1989, p. 138). According to Hayes (2017, p. 121), Galen's brave protest, however, did not extend to Germany's Jews, whom he believed to be "dangerous agents of modernity and Bolshevism."

4. Johnson (1999).

5. Friedlander (1995, p. 111) and Lifton (1986, p. 95). The so-called wild and children's euthanasia program continued throughout the war (Montague 2012, pp. 10, 13). 
6. Longerich $(2010$, p. 254).

7. Quoted in Klee et al. (1988, p. 69). Becker repeated this statement when terminally ill and no longer facing prosecution (see Browning 1985, p. 31).

8. Quoted in Klee et al. (1988, p. 69).

9. Arad (1987, p. 11).

10. MacLean (1999, pp. 15-16).

11. Quoted in Spektor (1993, pp. 60-61).

12. Quoted in Spektor (1993, p. 70). See also Adam (1989, p. 141).

13. Quoted in Arad et al. (1999, p. 420).

14. Rhodes (2002, p. 155).

15. Quoted in Spektor (1993, p. 61).

16. Quoted in Spektor (1993, p. 61).

17. Quoted in Rhodes (2002, p. 259).

18. Quoted in Spektor (1993, p. 55).

19. Quoted in Klee et al. (1988, p. 70).

20. Browning (1985, p. 64).

21. Quoted in Spektor (1993, p. 69). See also Langerbein (2004, p. 171).

22. When the choice to use gas vans or firearms is viewed from this perspective, an otherwise perplexing observation from Lucy Dawidowicz (1990, p. 176) suddenly makes greater sense: "In spring 1942 gas vans became more available to Einsatzgruppen, but whether or not they were used was a matter of individual taste. Höss, a man of schizophrenic sensibility, preferred gassing to shooting because he was "spared all these bloodbaths." In contrast, an Einsatzkommando chief held that an execution by shooting was "more honourable for both parties than killing by means of a gas truck." Höss, it would seem, concerned himself only with alleviating his men's stress, whereas for the Einsatzkommando chief shooting was, in a warped military sense, more honorable (perhaps because the shooters would likely pay a psychological price for taking their victims' lives).

23. Quoted in Naumann (1966, p. 46).

24. Adam (1989, pp. 140-141).

25. Hilberg (196la, p. 219). See also Chrostowski (2004, p. 8).

26. See van Pelt and Dwork (1996, p. 293) and Cesarani (2016, p. 424).

27. Cesarani (2016, p. 424).

28. Cesarani $(2016$, p. 432).

29. van Pelt and Dwork (1996, p. 294).

30. Cesarani (2016, p. 424) argues that Greiser's “consent was conditional on getting carte blanche to make room for the western Jews by removing 100,000 'sick' Polish Jews."

31. In support of this, soon afterward Łódź ghetto administrator Hans Biebow regularly attended the evacuation of Wartheland Jews from their 
smaller villages and towns, where he undertook selections of workers and non-workers. The former were transported to factories in the Łódź ghetto and the latter were sent off to be exterminated (Montague 2012, p. 72).

32. Montague (2012, pp. 40, 47).

33. Montague (2012, pp. 40-43, 46).

34. Gilbert (1986, pp. 219-221).

35. Montague (2012, pp. 43, 46-47).

36. Montague (2012, p. 44).

37. Quoted in Montague (2012, p. 44).

38. Quoted in Montague (2012, p. 45).

39. Quoted in Montague (2012, p. 45).

40. See Montague (2012, p. 45).

41. Browning (1985, p. 30).

42. Montague (2012, p. 47).

43. Browning (1985, pp. 30, 63).

44. Montague (2012, pp. 49, 51).

45. Montague (2012, p. 61).

46. Montague (2012, p. 49).

47. Consider, for example, Oberscharführer Fritz Swoboda, who received “a 12 marks bonus" for mass shootings he undertook in Czechoslovakia (quoted in Neitzel and Welzer 2012, p. 126).

48. Krakowski (2009, p. 34). Montague (2012, p. 57) puts the Lange Commando's bonus at 10 Reichsmarks per day, with the commandant receiving 15 Reichsmarks per day. Hayes (2017, p. 134) suggests German death camp workers received an extra 18 Reichsmarks per day, among other bonuses.

49. Montague (2012, p. 57).

50. Quoted in Montague (2012, p. 56).

51. Montague (2012, pp. 55-56). During the mass shooting campaign, some Einsatzgruppen forces would approach the Wehrmacht and request they "merely provide security," but then later drew them further into the execution process (see Beorn 2014, pp. 72, 76-77).

52. Quoted in Krakowski $(2009$, p. 40).

53. Montague (2012, p. 57).

54. Kühl (2016, p. 90).

55. Kühl (2016, p. 125).

56. Kühl (2016, p. 41).

57. Browning (1985, p. 30).

58. Montague (2012, p. 54).

59. Krakowski (2009, p. 36) and Montague (2012, p. 64).

60. Montague (2012, p. 65).

61. Krakowski (1993, p. 91). 
62. Montague (2012, p. 65$)$.

63. Montague (2012, p. 66). Using gas to deal with the "Gypsy problem" obviously proved more popular than the method suggested by racial scientist Robert Ritter. During the winter of 1941/1942, Ritter proposed at an academic conference that the Nazis send ships into the Mediterranean loaded with Gypsies (about 30,000 passengers each) and then bomb them (Müller-Hill 1988, p. 59).

64. Browning (2004a, p. 418), Montague (2012, p. 205), Schelvis (2007, p. 18).

65. Quoted in Matthäus (2004, p. 300).

66. It is true that, as a group, the Jews only made up a small proportion of the Nazi's potential slave-labor pool, especially compared to, say, the far more numerous non-Jewish Poles. Nonetheless, the Jews were still a source of slave labor under the hegemony of a group who were no longer in a position to be fussy.

67. Angrick and Klein (2009, p. 260).

68. Cesarani (2016, p. 454) and Hayes (2017, p. 124). Also, the original meeting location was not at the Wannsee lakeside villa (Cesarani 2016, p. 454).

69. Cesarani (2016, pp. 454-455).

70. van Pelt and Dwork (1996, p. 275).

71. Quoted in Roseman (2002, p. 100).

72. Friedländer $(2007$, p. 340).

73. Longerich (2012, p. 555$)$.

74. Quoted in Friedländer (2007, p. 340).

75. Quoted in Friedländer (2007, p. 340).

76. Quoted in Friedländer (2007, p. 340). See also Longerich (2012, pp. 555-556).

77. Hayes (2017, p. 164).

78. Quoted in Browning (1978, p. 78).

79. Marcuse (2001, p. 41). The origins of this idea trace back to Einsatzgruppe C in September 1941 (Longerich 2010, pp. 314-315).

80. Friedländer $(2007$, p. 341$)$.

81. Cesarani $(2004$, p. 301$)$. The last part of the minutes states, "in conclusion the various possible kinds of solution were discussed" (quoted in Roseman 2002, p. 103). See also Friedländer (2007, p.142).

82. Angrick and Klein (2009, p. 261). Having said this, had FriedrichWilhelm Krüger attended the Wannsee Conference instead of sending his assistant, he too would have had experience in such matters.

83. Fleming (1984, p. 94).

84. “...Lange was ... doubtless invited by Heydrich to the conference ... to describe his practical experiences with the Final Solution to the other participants gathered ... at Grosser Wannsee" (Fleming 1984, p. 93). 
Padfield (1990) also concludes, "it is difficult to understand why Lange was there or why the conference had to be postponed for him unless he was to explain the practicalities of liquidation" (p. 357).

85. It can be assumed that due to Lange's central role in Riga, he would have known about the plan to send gas vans to Riga (an initiative that, due to Wetzel's previously mentioned 25 October 1941 letter to Lohse about Brack setting up gassing camps in Riga and Minsk, traced back three months before the Wannsee Conference).

86. Longerich (2010, p. 292).

87. Quoted in Dawidowicz (1990, p. 176).

88. Fleming (1984, p. 110).

89. See Browning (2004a, p. 419). Longerich (2010, p. 263) argues Eichmann arrived later in the spring of 1942. Montague (2012, p. 94) only states that Eichmann visited Chełmno "[s]hortly after the camp began operations...."

90. See von Lang (1982, p. 71 , as cited in Adam 1989, p. 142), with Fleming (1984, p. 74) stating that, "before the end of 1941, Müller again sent Eichmann out for an extermination camp report, this time to Kulmhof (Chelmno)...."

91. Quoted in von Lang (1983, p. 77-78, as cited in Montague 2012, p. 95).

92. Quoted in Arad (1987, pp. 12-13).

93. A month before the Wannsee Conference, "Hans Frank admitted, when speaking in mid-December 1941 of the need to liquidate the Jews of the Generalgouvernement, that he did not know how this could be done: 'We can't shoot these 3.5 Million Jews,' he declared, 'we can't poison them, but will have somehow to take steps leading somehow to a success in annihilation (Vernichtungserfolg) in connection with the largescale measures under discussion by the Reich"” (Kershaw 2000, p. 128).

94. Quoted in Roseman (2002, p. 102).

95. Quoted in Krausnick and Broszat (1970, p. 228).

96. Quoted in Longerich (2012, p. 560).

97. Quoted in Longerich (2012, p. 560).

98. Benz (1999, pp. 72-73).

99. Quoted in Krakowski (1993, pp. 74-75).

100. Adam (1989, p. 142).

101. As one T4 physician wrote in his 1940 letter of resignation from the euthanasia program, "despite my intellectual understanding and good will, I cannot help stating that I am temperamentally not fitted for this [...] I prefer to see clearly and to recognize that I am too gentle for this work than to disappoint you later" (quoted in Glover 1999, p. 347).

102. Montague (2012, p. 76).

103. Montague (2012, pp. 56, 57, 67, 68, 69). 
104. Montague (2012, pp. 61, 69).

105. Montague (2012, p. 76).

106. Quoted in Krakowski (1993, p. 83).

107. Montague (2012, p. 77).

108. Montague (2012, p. 76).

109. Montague (2012, p. 76).

110. Quoted in Krakowski (1993, p. 84).

111. Quoted in Krakowski (1993, p. 84).

112. Initially, the Polish prisoners may have felt they had little choice but to help the Germans, but as they became more implicated in the killing process, they gained the appearance of trusted collaborators (see Montague 2012, pp. 58-60). As one Pole, Henryk Maliczak, conceded: "we were on friendly terms with the Germans. They considered us employees [pracownicy]. The German administrators of the camp never spoke to us about the possibility of escape. Besides, as far as I know, none of us had any intention of escaping. Moreover, we were never threatened that our family would have a problem if one of us escaped. Objectively speaking, we had it pretty good" (quoted in Montague 2012, p. 58).

113. Quoted in Klee et al. (1988, p. 218).

114. Quoted in Krakowski (1993, p. 86).

115. Montague (2012, p. 206). If vans driven through the streets with the sounds of screaming people coming from their rear cabins failed to alert the local community to the camp's purpose (unlikely), the time one van's back door swung open on route and the bodies of dying victims sprawled out across the street certainly would have (see Montague 2012 , p. 94). Also, over drinks the Polish collaborators informed the locals what was taking place in their midst (Montague 2012, p. 59).

116. Montague (2012, p. 79).

117. Krakowski (1993, p. 84).

118. Quoted in Krakowski (1993, p. 87).

119. Krakowski (1993, p. 77).

120. Montague (2012, pp. 113-114).

121. Montague (2012, p. 114).

122. Montague (2012, p. 111).

123. Quoted in Krakowski (1993, p. 87).

124. Montague (2012, p. 60).

125. Montague (2012, pp. 98-99, 112).

126. Montague $(2012$, p. 60). In conflict with the assertion that Germans avoided the more horrific tasks, one survivor notes that at Chełmno, "two German civilians approached and carried out a thorough search of the corpses, looking for valuables. They tore off necklaces, pulled rings 
off fingers, pulled out gold teeth. They even looked in the anuses and, with the women, genitalia" (quoted in Cesarani 2016, p. 462).

127. Quoted in Krakowski (1993, p. 89).

128. Montague (2012, pp. 53-54).

129. Arad (1987, p. 11), Krakowski (1993, p. 84), Montague (2012, pp. 93 , $107,162)$.

130. Montague (2012, p. 78).

131. Having said this, on 5 June 1942 the RSHA estimated that it would take six years for 30 gas vans to exterminate all 11 million of Europe's Jews (Müller-Hill 1988, p. 48).

132. Montague (2012, p. 67).

133. Montague (2012, p. 67).

134. Montague (2012, p. 68 )

135. Cesarani (2016, p. 465).

136. Montague (2012, p. 68).

137. Montague (2012, p. 114).

138. Arad (1987, p. 170).

139. Somewhat like Milgram, Himmler failed to consider that with time power always changes and those who previously abused their positions of greater power are later sometimes required to explain themselves. Once abusers of power realize this, they are often tempted, as both Milgram and Himmler were, to engage in cover-ups. For example, after Baumrind's (1964) critique of his research, Milgram never published his incomparably unethical Relationship condition (as he had earlier promised) and also told a variety of lies about his data collection process (see Perry 2012; Russell 2014). And as the Red Army moved west, Himmler attempted to eliminate evidence of his crimes.

140. Rubenstein and Roth (1987, p. 151).

141. See Arad (1987, pp. 170-171).

142. Arad (1987, p. 171).

143. Montague (2012, p. 185).

144. Montague (2012, p. 188).

145. Hilberg (1961b, p. 84).

146. Montague (2012, p. 3).

147. Browning (2004b, pp. 188-189).

148. Cesarani argues Himmler may have approached Globocnik (2016, p. 468).

149. Quoted in Musial (2000, p.115, as cited in Lower 2002, p. 2). See also Longerich (2012, p. 547). As Cesarani (2016, p. 468) notes, "the decisions that led to this human cataclysm are obscure." 
150. Musial (2002, p. 195; 2000, pp. 113, as cited in Kühl 2016, p. 139). Globocnik's initial plan in building Belzec may also have been motivated by his concern over political security (Longerich 2012, p. 547).

151. Longerich (2010, p. 295).

152. Browning (2004b, p. 189).

153. Quoted in Arad (1987, p. 17). As Friedlander argues, "In September of 1941 Philipp Bouhler and Viktor Brack visited Globocnik in Lublin. Although at Nuremberg Brack denied that this visit had anything to do with the Final Solution, it seems likely that they discussed their future collaboration" (1994, p. 54).

154. Krausnick (1968, p. 97).

155. Hayes (2017, pp. 121-122).

156. Browning (2004b, p. 189).

157. Adam (1989, p. 138).

158. Longerich (2010, p. 280).

159. Arad (1987, p. 24). Benz (1999, p. 144) suggests that Wirth worked at Chełmno and Chrostowski (2004, pp. 6-7) and Padfield (1990, p. 372) go further, arguing he co-designed and helped build the center. Then again, Montague (2012) makes no mention of any connections between Wirth and Chełmno.

160. Arad (1993, p. 107).

161. Dawidowicz (1990, p. 175).

162. Quoted in Arad (1993, pp. 107-108).

163. Quoted in Lanzmann (1995, p. 53).

164. Arad (1987, p. 26).

165. Arad (1993, p. 109).

166. Arad (1987, p. 26). The transition from canisters to motor-generated exhaust fumes may have been more complicated than outlined here. According to Polish worker Stanislaw Kozak, the long-term intention at Belzec was to use carbon monoxide gas produced by large coal furnaces, which he installed but were, at some point, obviously replaced (Schelvis 2007 , p. 98). Perhaps because this innovation failed to prove effective, no coal furnaces were installed at the next and "improved" Sobibor extermination camp (p. 100).

167. Browning (1998, p. xv).

168. Pohl (1993, as cited in Friedländer 1997, p. 284). See also Longerich (2012, p. 547).

169. Quoted in Klee et al. (1988, p. 228).

170. Arad (1987, p. 23).

171. Arad (1987, p. 30). In conflict with this, Kershaw (2000, p. 129) argues that it was not until late April and early May 1942 that it became clear to all involved that Wirth's plan to build three industrial-sized 
extermination camps in the General Government was likely to be a highly lethal "success." Consequently, it was also around this point in time that Globocnik was given the green light to try and exterminate all the Jews in the General Government (Kershaw 2000, p. 129). But why would the green light for Operation Reinhard come a month or two after construction at Sobibor had started? The go-ahead for the wider project by higher-ups surely came before late April.

172. Cesarani (2016, p. 470).

173. Schelvis $(2007$, p. 28$)$.

174. Arad (1993, p. 122).

175. Stangl as cited in Schelvis $(2007$, p. 33$)$.

176. Adam $(1989$, p. 146). Arad $(1987$, p. 123) puts the figure at 600 per gassing.

177. Arad (1987, p. 123).

178. Arad (1993, p. 122).

179. Adam (1989, p. 146) and Arad (1993, p. 122).

180. Cesarani (2016, p. 468).

181. See van Pelt and Dwork (1996, p. 313).

182. Adam (1989, p. 146) and Arad (1987, p. 80).

183. Quoted in Arad (1987, p. 47). See also Bloxham and Kushner (2005, p. 136).

184. Quoted in van Pelt and Dwork (1996, p. 313). Then again, apparently Kersten was not the most reliable of sources (Kershaw 2000, p. 113).

185. Aly (2006, p. 31).

186. Quoted in Aly (2006, p. 31). Bolstering the German's patronizing view toward Eastern European "natives," as Hitler said in mid-September 1941 to his inner circle: "We'll give the Ukrainians head scarves, glass jewelry, and everything else colonized peoples like" (quoted in Aly 2006, p. 116).

187. Arad (1993, p. 115).

188. Quoted in Arad (1987, p. 87).

189. Arad (1987, p. 87).

190. Quoted in Arad (1987, p. 172).

191. Arad (1987, p. 171).

192. Quoted in Arad (1987, p. 172). See also Schelvis (2007, pp. 99-100).

193. Arad (1987, p. 87; 1993, p. 127).

194. Adam (1989, p. 146).

195. Hayes (2017, p. 127).

196. See also Arad (1993, p. 127).

197. Quoted in Friedlander (1995, p. 299).

198. Quoted in Arad (1987, p. 94).

199. Arad (1993, p. 132). 
200. Arad (1987, pp. 73-74, 123) estimates that the killing capacity of the new chambers at Belzec and Sobibor was about 2000 and 1300 per gassing cycle, respectively. And Treblinka's knew chambers were capable of killing about 2300 or 3800 per gassing (pp. 119-120). Adam (1989) provides more conservative estimates.

201. Quoted in Arad (1987, pp. 120-121). See also Adam (1989, p. 146).

202. Arad (1987, p. 130).

203. Arad (1987, pp. 131, 165).

204. Schelvis (2007, pp. 93-94).

205. Schelvis $(2007$, p. 36).

206. Arad (1993, p. 137) and Arad (1987, p. 165).

207. Hilberg (2003, p. 1320) provides the lower figure of 434,508 at Belzec.

208. Sobibor had fewer victims than Belzec and Treblinka because it was the first extermination center to introduce cremation facilities and the first to be closed down. There were also periods when Sobibor's railway line could not be used to transport victims because it had either been closed for repairs or was prioritized for military transports (Adam 1989, p. 146). Schelvis (2007, pp. 28-29, 47-48, 103-104) more specifically notes that Sobibor, unlike Belzec and Treblinka, only had access to a single railway line that also ran through a marshland. In the summer, the line was damaged by subsidence and frequently needed repairs. This difference in infrastructure and conditions largely explains why Sobibor was not nearly as destructive at the other two camps.

209. Hilberg (1980, p. 93 ).

210. Hayes $(2017$, p. 131$)$.

211. Aly (2006, p. 285).

212. de Mildt (1996, p. 16).

213. Rees (2005, pp. 149-150).

214. Quoted in Klee et al. (1988, p. 241).

215. Schelvis (2007, p. 105).

216. Quoted in Klee et al. (1988, pp. 242, 244).

217. Quoted in Patterson (2002, p. 133).

218. Quoted in Arad (1993, p. 122).

219. Schelvis $(2007$, p. 70$)$.

220. Schelvis (2007, pp. 71, 122).

221. Arad (1987, pp. 254-256).

222. What mattered most in terms of the so-called Jeckeln schedule was "the continual flow" of victims (Angrick and Klein 2009, pp. 155, 149). One perpetrator's area of specialization "was to accelerate procedures during "tie ups"” (p. 149). Victim docility was also an essential ingredient for killing efficiency during Jeckeln's mass shootings. Two subordinate figures in Jeckeln's ranks were well aware that "the success of the endeavor 
depended on deceiving these 'half-starved, yammering figures' and preventing panic from ensuing" (p. 142).

223. As Stangl later implied: For the perpetrators, victim docility was a much more important ingredient than perpetrator hatred. In his words, "It has nothing to do with hate. They were so weak; they allowed everything to happen-to be done to them. They were people with whom there was no common ground, no possibility of communication-that is how contempt is born" (quoted in Sereny 1983, pp. 232-233, as cited in Markusen and Kopf 1995, p. 187). Thus, victim weakness promoted docility, and victim docility trumped the importance of perpetrator hatred.

224. Sereny (1974, p. 200). See also Arad (1987, pp. 122-123).

225. Arad (1987, p. 86).

226. Arad (1987, p. 86).

227. This is according to survivor Dov Freiberg (Arad 1987, p. 75).

228. Schelvis $(2007$, p. 74$)$.

229. Arad (1993, pp. 136-137).

230. Arad (1987, pp. 322-341).

231. Quoted in Lanzmann (1995, pp. 148-149).

232. Arad (1993, p. 137).

233. See Marszałec (1986, pp. 130-131).

234. Arad (1987, pp. 365-369).

235. Arad (1987, p. 368).

236. Browning (1992, p. 163).

237. Browning (1992, p. 163). See also Benz (1999, pp. 141-142) and Marszałec (1986, pp. 130-134). Majdanek had a Zyklon-B gas chamber, so why was this not used for Operation Harvest Festival? According to survivor Jerzy Kwiatkowski "Only a relatively small number of people could be killed each day in the gas chamber" (quoted in Kranz 2007, p. 53). Although Majdanek only had a small gas chamber, it did have a fairly large crematorium. However, both facilities were located at different ends of the camp. Therefore, the setup was not conducive for the purposes of large-scale extermination and would have been of little use to Himmler (see Katz 2005, p. 416; Marszałec 1986, pp. 8-9). Perhaps even more importantly, Marszałec notes (without explanation) that the gas chambers in Majdanek only operated from September 1942 until September 1943, therefore before Operation Harvest Festival (p. 129). In conflict with this, Adam (1989, p. 153) suggests that Majdanek's gas chamber was closed down sometime in November 1943 (perhaps after Operation Harvest Festival). Although he adds, "A partial enigma remains concerning the methods used at Majdanek to gas the victims" (p. 152).

238. Matthäus (2007, p. 234). 


\section{REFERENCES}

Adam, U. D. (1989). The gas chambers. In F. Furet (Ed.), Unanswered questions: Nazi Germany and the genocide of the Jews (pp. 134-154). New York: Schocken Books.

Aly, G. (2006). Hitler's beneficiaries: Plunder, racial war, and the Nazi welfare state. New York: Metropolitan Books, Henry Holt and Company.

Angrick, A., \& Klein, P. (2009). The "final solution" in Riga: Exploitation and annibilation, 1941-1944. New York: Berghahn Books.

Arad, Y. B. (1987). Belzec, Sobibor, Treblinka: The Operation Reinhard death camps. Bloomington: Indiana University Press.

Arad, Y. B. (1993). Operation Reinhard: Gas chambers in Eastern Poland. In E. Kogon, H. Langbein, \& A. Rückerl (Eds.), Nazi mass murder: A documentary history of the use of poison gas (pp. 102-138). New Haven, CT: Yale University Press.

Arad, Y., Gutman, I., \& Margaliot, A. (1999). Documents on the Holocaust: Selected sources on the destruction of the Jews of Germany and Austria, Poland, and the Soviet Union (8th ed.). Lincoln: University of Nebraska Press.

Baumrind, D. (1964). Some thoughts on ethics of research: After reading Milgram's 'behavioral study of obedience'. American Psychologist, 19(6), $421-423$.

Benz, W. (1999). The Holocaust: A German historian examines the genocide. New York: Columbia University Press.

Beorn, W. W. (2014). Marching into darkness. Cambridge, MA: Harvard University Press.

Bloxham, D., \& Kushner, T. (2005). The Holocaust: Critical historical approaches. Manchester, UK: Manchester University Press.

Browning, C. R. (1978). The final solution and the German Foreign Office: A study of Referat D III of Abteilung Deutschland 1940-1943. New York: Holmes and Meier.

Browning, C. R. (1985). Fateful months: Essays on the emergence of the final solution. New York: Holmes and Meier.

Browning, C. R. (1992). Ordinary men: Reserve Police Battalion 101 and the final solution in Poland. New York: HarperCollins.

Browning, C. R. (1998). Ordinary men: Reserve Police Battalion 101 and the final solution in Poland. New York: Harper Perennial.

Browning, C. R. (2004a). The origins of the final solution: The evolution of Nazi Jewish policy, September 1939-March 1942. Lincoln: University of Nebraska Press.

Browning, C. R. (2004b). The decision-making process. In D. Stone (Ed.), The historiography of the Holocaust (pp. 173-196). New York: Palgrave Macmillan. 
Cesarani, D. (2004). Eichmann: His life and crimes. London: William Heinemann.

Cesarani, D. (2016). Final solution: The fate of the Jews 1933-1949. London: Macmillan.

Chrostowski, W. (2004). Extermination camp Treblinka. London: Vallentine Mitchell.

Dawidowicz, L. S. (1990). The war against the Jews 1933-1945 (10th ed.). Harmondsworth, UK: Penguin.

de Mildt, D. (1996). In the name of the people: Perpetrators of genocide in the reflection of their post-war prosecution in West Germany-The 'Euthanasia' and 'Aktion Reinhard' trial cases. London: Martinus Nijhoff.

Evans, S. E. (2004). Forgotten crimes: The Holocaust and people with disabilities. Chicago: Ivan R. Dee.

Fleming, G. (1984). Hitler and the final solution. Berkeley: University of California Press.

Friedlander, H. (1994). Euthanasia and the final solution. In D. Cesarani (Ed.), The final solution: Origins and implementation (pp. 51-61). New York: Routledge.

Friedlander, H. (1995). The origins of Nazi genocide: From euthanasia to the final solution. Chapel Hill: University of North Carolina Press.

Friedländer, S. (1997). Nazi Germany and the Jews: The years of persecution, 1933-1939. New York: HarperCollins.

Friedländer, S. (2007). The years of extermination: Nazi Germany and the Jews, 1939-1945. New York: Harper Perennial Publishers.

Gilbert, M. (1986). The Holocaust: The Jewish tragedy. London: William Collins Sons.

Glover, J. (1999). Humanity: A moral history of the twentieth century. London: Pimlico.

Hayes, P. (2017). Why? Explaining the Holocaust. New York: W. W. Norton.

Hilberg, R. (1961a). The destruction of the European Jews. Chicago: Quadrangle Books.

Hilberg, R. (1961b). The destruction of the European Jews (Vols. 1-3). New York: Holmes \& Meier.

Hilberg, R. (1980). The anatomy of the Holocaust. In H. Friedlander \& S. Milton (Eds.), The Holocaust: Ideology, bureaucracy, and genocide (The San José papers) (pp. 85-94). Millwood, NY: Kraus International Publications.

Hilberg, R. (2003). The destruction of the European Jews (3rd ed., Vols. 1-3). London: Yale University Press.

Johnson, E. A. (1999). Nazi terror: The Gestapo, Jews, and ordinary Germans. New York: Basic Books.

Katz, E. (2005). On the neutrality of technology: The Holocaust death camps as a counter-example. Journal of Genocide Research, 7(3), 409-421. 
Kershaw, I. (2000). The Nazi dictatorship: Problems and perspectives of interpretation (2nd ed.). London: Arnold.

Klee, E., Dressen, W., \& Riess, V. (Eds.). (1988). "The good old days": The Holocaust as seen by its perpetrators and bystanders. New York: Free Press.

Krakowski, S. (1993). The stationary gas vans at Kulmhof. In E. Kogon, H. Langbein, \& A. Rückerl (Eds.), Nazi mass murder: A documentary history of the use of poison gas (pp. 73-101). New Haven, CT: Yale University Press.

Krakowski, S. (2009). Chetmno: A small village in Europe: The first Nazi mass extermination camp. Jerusalem: Yad Vashem.

Kranz, T. (2007). Extermination of Jews at the Majdanek concentration camp. Lublin: Państwowe Muzeum na Majdanku.

Krausnick, H. (1968). The persecution of the Jews. In H. Krausnick, H. Buchheim, M. Broszat, \& H. A. Jacobsen (Eds.), Anatomy of the SS state (pp. 1-124). London: Collins.

Krausnick, H., \& Broszat, M. (1970). Anatomy of the SS state. St Albans, UK: Paladin.

Kühl, S. (2016). Ordinary organizations: Why normal men carried out the Holocaust. Cambridge, UK: Polity Press.

Langerbein, H. (2004). Hitler's death squads: The logic of mass murder. College Station: Texas A\&M University Press.

Lanzmann, C. (1995). Shoah: The complete text of the acclaimed Holocaust film. New York: Da Capo Press.

Lifton, R. J. (1986). The Nazi doctors: Medical killing and the psychology of genocide. New York: Basic Books.

Longerich, P. (2010). Holocaust: The Nazi persecution and murder of the Jews. Oxford, UK: Oxford University Press.

Longerich, P. (2012). Heinrich Himmler. Oxford, UK: Oxford University Press.

Lower, W. (2002). "Anticipatory obedience" and the Nazi implementation of the Holocaust in the Ukraine: A case study of the central and peripheral forces in the Generalbezirk Zhytomyr, 1941-1944. Holocaust and Genocide Studies, $16(1), 1-22$.

MacLean, F. L. (1999). The field men: The SS officers who led the Einsatzkommandos-The Nazi mobile killing units. Atglen, PA: Schiffer Military History.

Marcuse, H. (2001). Legacies of Dachau: The uses and abuses of a concentration camp, 1933-2001. New York: Cambridge University Press.

Markusen, E., \& Kopf, D. (1995). The Holocaust and strategic bombing: Genocide and total war in the twentieth century. Boulder, CO: Westview Press.

Marszałec, J. (1986). Majdanek: The concentration camp in Lublin. Warsaw: Interpress. 
Matthäus, J. (2004). Operation Barbarossa and the onset of the Holocaust, June-December 1941. In C. R. Browning (Ed.), The origins of the final solution: The evolution of Nazi Jewish policy, September 1939-March 1942 (pp. 248-308). Lincoln: University of Nebraska Press.

Matthäus, J. (2007). Controlled escalation: Himmler's men in the summer of 1941 and the Holocaust in the occupied Soviet territories. Holocaust and Genocide Studies, 21(2), 218-242.

Montague, P. (2012). Chetmno and the Holocaust: The history of Hitler's first death camp. London: I.B. Tauris.

Müller-Hill, B. (1988). Murderous science: Elimination by scientific selection of Jews, Gypsies, and others, Germany 1933-1945. New York: Oxford University Press.

Naumann, B. (1966). Auschwitz. New York: Praeger.

Neitzel, S., \& Welzer, H. (2012). Soldiers: On fighting, killing and dying: The secret Second World War transcripts of German POWs. New York: Alfred A. Knopf.

Padfield, P. (1990). Himmler: Reichsführer-SS. London: Macmillan.

Patterson, C. (2002). Eternal Treblinka: Our treatment of animals and the Holocaust. New York: Lantern books.

Perry, G. (2012). Beyond the shock machine: The untold story of the Milgram obedience experiments. Melbourne: Scribe.

Rees, L. (2005). Auschwitz: A new history. New York: BBC Books.

Rhodes, R. (2002). Masters of death: The SS-Einsatzgruppen and the invention of the Holocaust. New York: Alfred A. Knopf.

Roseman, M. (2002). The villa, the lake, the meeting: Wannsee and the final solution. London: Penguin Press.

Rubenstein, R. L., \& Roth, J. K. (1987). Approaches to Auschwitz: The Holocaust and its legacy. Atlanta, GA: John Knox Press.

Russell, N. J. C. (2014). Stanley Milgram's obedience to authority "relationship" condition: Some methodological and theoretical implications. Social Sciences, 3(2), 194-214.

Schelvis, J. (2007). Sobibor: A history of a Nazi death camp. Oxford: Berg.

Sereny, G. (1974). Into that darkness: From mercy killing to mass murder. London: Pimlico.

Specktor, S. (1993). Killing in the gas vans behind the front. In E. Kogon, H. Langbein, \& A. Rückerl (Eds.), Nazi mass murder: A documentary history of the use of poison gas (pp. 52-72). New Haven, CT: Yale University Press.

van Pelt, R. J., \& Dwork, D. (1996). Auschwitz: 1270 to the present. New York: W. W. Norton. 
Open Access This chapter is licensed under the terms of the Creative Commons Attribution 4.0 International License (http://creativecommons.org/licenses/ by $/ 4.0 /$ ), which permits use, sharing, adaptation, distribution and reproduction in any medium or format, as long as you give appropriate credit to the original author(s) and the source, provide a link to the Creative Commons licence and indicate if changes were made.

The images or other third party material in this chapter are included in the chapter's Creative Commons licence, unless indicated otherwise in a credit line to the material. If material is not included in the chapter's Creative Commons licence and your intended use is not permitted by statutory regulation or exceeds the permitted use, you will need to obtain permission directly from the copyright holder.

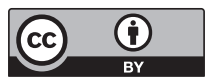

